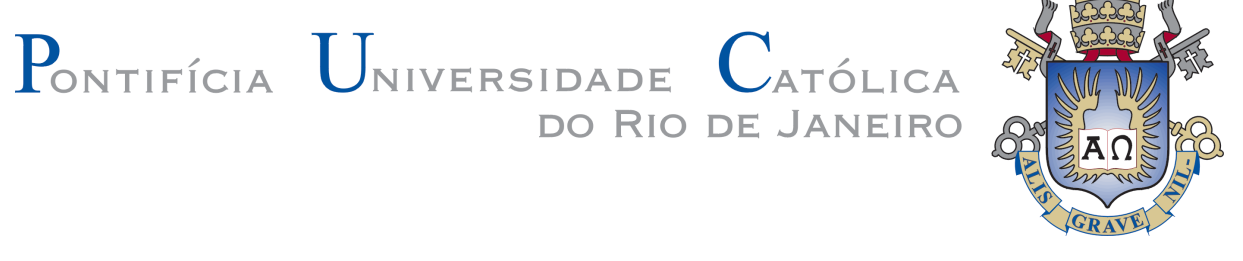

Tito Mendes da Costa

CRM em mídia social na visão de auto-atendimento

Dissertação de Mestrado

Dissertação apresentada como requisito parcial para obtenção do título de Mestre pelo Programa de PósGraduação em Administração de Empresas da PUCRio.

Orientador: Prof. Jorge Brantes Ferreira

Rio de Janeiro

Abril de 2014 


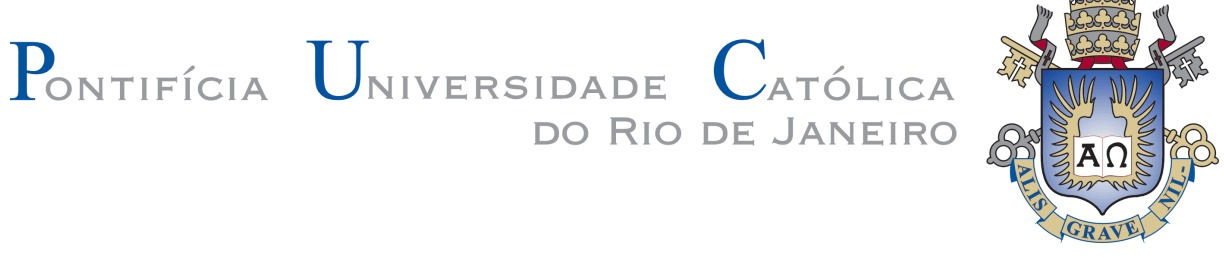

Tito Mendes da Costa

\title{
CRM em mídia social na visão de auto-atendimento
}

\begin{abstract}
Dissertação apresentada como requisito parcial para obtenção do título de Mestre pelo Programa de PósGraduação em Administração de Empresas da PUC-Rio. Aprovada pela Comissão Examinadora abaixo assinada.
\end{abstract}

\section{Prof. Jorge Brantes Ferreira} Orientador Departamento de Administração - PUC-Rio

Prof. Paulo César de Mendonça Motta Departamento de Administração - PUC-Rio

Prof ${ }^{\mathrm{a}}$. Paula Castro Pires de Souza Chimenti Instituto COPPEAD de Administração - UFRJ

Prof ${ }^{a}$. Mônica Herz Vice-Decana de Pós-Graduação do CCS - PUC-Rio 
Todos os direitos reservados. É proibida a reprodução total ou parcial do trabalho sem autorização da universidade, do autor e do orientador.

Tito Mendes da Costa

Graduou-se como Técnico em Eletrônica pela Escola Técnica de Eletrônica - Francisco Moreira da Costa (ETEFMC) em 1998 e em Engenharia Elétrica modalidade Eletrônica com ênfase em Telecomunicações pelo Instituto Nacional de Telecomunicações (INATEL) em 2003. Iniciou sua carreira profissional como Gerente de Produtos e aos poucos se aproximou da carreira comercial atuando como Engenheiro de Pré-Vendas, Consultor de Soluções e Gerente de Contas, área em que atuou por 10 anos sempre em empresas do setor de telecomunicações, fabricantes de equipamentos ou operadoras. Depois de uma pequena experiência como empreendedor de uma representação de equipamentos para radioterapia, retornou ao mercado de operadoras atuando como Gerente de Planejamento Estratégico e Comercial e hoje é Gerente de Marketing de Verticais em uma multinacional do setor de TI.

Ficha Catalográfica

Costa, Tito Mendes da

CRM em mídia social na visão de auto-atendimento / Tito Mendes da Costa ; orientador: Jorge Brantes. 2014.

97 f. : il. ; $30 \mathrm{~cm}$

Dissertação (mestrado) - Pontifícia Universidade Católica do Rio de Janeiro, Departamento de Administração, 2014.

Inclui bibliografia

1. Administração - Teses. 2. Mídias Sociais. 3. Narcisismo Social. 4. Prontidão para Tecnologia. 5. Comportamento do Consumidor. 6. Lógica de Serviço Dominante. 7. Tecnologias de Auto-Serviço. I. Brantes, Jorge. II. Pontifícia Universidade Católica do Rio de Janeiro. Departamento de Administração. III. Título. 


\section{Agradecimentos}

Ao meu orientador, Jorge Brantes, por ter aceitado o desafio de estudar esse fenômeno inovador comigo, sempre disposto a testar novas hipóteses e modelos afim de lapidar um novo modelo de aceitação de tecnologia. Por me orientar, ensinar, sugerir, apressar, apoiar e cobrar - sempre na medida certa.

À minha família que muito bem me educou e me deu as ferramentas e valores para chegar até aqui.

Aos amigos que influenciaram minha decisão de ingressar no mestrado e que em tantas conversas proveitosas ajudaram a despertar um dom que não sabia existir além de uma grande paixão pelo Marketing. 


\section{Resumo}

Costa, Tito Mendes da; Ferreira, Jorge Brantes. CRM em mídia social na visão de auto-atendimento. Rio de Janeiro, 2014. 97p. Dissertação de Mestrado - Departamento de Administração, Pontifícia Universidade Católica do Rio de Janeiro.

As gerações atuais (Y, Z, Me...) são conhecidas como as Gerações Silenciosas pois fazem uso extensivo de mecanismos de mídias sociais e serviços de mensagem (SMS e mais recentemente Whatsapp) em lugar de serviços de voz. Tais gerações, que começam a ser responsáveis por grande parte do mercado consumidor, se sentem mais à vontade com a troca de mensagens vis-à-vis as relações diretas que normalmente ocorrem na comercialização de serviços e suporte pós-venda, facilitando a ampliação do escopo de soluções de auto-serviço e auto-atendimento para esse público. Nesse prisma, torna-se interessante entender de que forma esses novos consumidores se comportam nas mídias sociais e as relações e questões que os levam a adotar novas tecnologias e consumir novos produtos e serviços que podem trazer implicações significativas tanto para a evolução da teoria acadêmica como para gestores de empresas. No presente estudo é proposto um modelo conceitual para avaliação da intenção de adoção de uma nova tecnologia, integrando relações de endosso nas mídias sociais aos efeitos moduladores que o Narcisismo Social (narcisismo nas mídias sociais) podem causar sobre a dimensão afetiva uma vez que o consumo em si não seja uma necessidade fim, mas sim um meio para se auto afirmar. Surveys online com consumidores de serviço de telefonia móvel foram analisados através de equações estruturais afim de se testar se as hipóteses criadas através de indícios de relações observados na revisão da literatura foram ou não confirmadas.

\section{Palavras-chave}

Mídias Sociais; Narcisismo Social; Prontidão para Tecnologia; Comportamento do Consumidor; Lógica de Serviço Dominante; Tecnologias de Auto-Serviço. 


\section{Abstract}

Costa, Tito Mendes da; Ferreira, Jorge Brantes. Social CRM through selfservice Technologies. Rio de Janeiro, 2014. 97p. MSc. Dissertation Departamento de Administração, Pontifícia Universidade Católica do Rio de Janeiro.

Current generations (Y, Z, Me...) are known as the Silent Generation because they make extensive use of mechanisms of social media and messaging (SMS and more recently Whatsapp) rather than voice services. Such generations, which begin to be responsible for much of the consumer market, feel more comfortable with the message exchange instead of direct relations that normally occur in services commercialization and post-sales support, facilitating the expansion self-service solutions for this public. In this perspective, it is interesting to understand how these new consumers behave in social media and the relationships and issues that lead them to adopt new technologies and consume new products and services that can bring significant implications for the evolution of both academic theory and for managers. In the present study we propose a conceptual model to evaluate the intention to adopt a new technology, integrating the social relations of endorsement to the modulatory effects that social media Narcissism (Narcissism in social media) may have on the affective dimension since consumption itself is not an end but rather a means to assert themselves. Online surveys with mobile phone service consumers were analyzed through structures equation modeling in order to test if the hypotheses created by evidence of the relationships observed in the literature review were confirmed or not.

\section{Keywords}

Social Media; Social Narcissism; Technology Readiness; Consumer Behavior; Service-Dominant Logic; Self-service Technologies. 


\section{Sumário}

1 Introdução 14

1.1. Problema de Pesquisa 14

$\begin{array}{ll}\text { 1.2. Objetivos } & 17\end{array}$

$\begin{array}{ll}\text { 1.3. Questões de Pesquisa } & 17\end{array}$

1.4. Relevância do Estudo 17

$\begin{array}{ll}\text { 1.5. Delimitações do Estudo } & 18\end{array}$

2 Referencial Teórico 19

2.1. Marketing de Serviços $\quad 19$

2.1.1. Lacunas de Serviço 20

2.1.2. Service Value Proposition (SVP) 21

2.1.3. Lógica de Serviço Dominante (S-D Logic) 22

2.1.4. Self-Service Technologies 23

2.2. Customer Relationship Management (CRM) 25

2.2.1. Web 2.0, 2.5 ou 3.0? 25

2.2.2. CRM Social (SCRM) 26

2.3. Fatores Psicossociais $\quad 29$

2.3.1. Narcisismo 29

2.3.2. Geração Digital 31

2.4. Modelo Conceitual de Adoção de Tecnologia 32

2.4.1. Teoria da Aceitação de Tecnologia 33

2.4.2. Teoria da Socialização entre Consumidores 34

2.4.3. Difusão de Inovações 36

2.4.4. Modelo Conceitual Proposto 36

3 Metodologia da Pesquisa 43

3.1. Tipo de Pesquisa 43

3.2. Operacionalização das variáveis 44

3.2.1. Definição operacional das variáveis 45

3.2.2. Procedimentos de tradução e adaptação das escalas utilizadas 47 
3.2.3. Pré-teste do instrumento de pesquisa

3.3. População e amostra 48

3.3.1. População 48

3.3.2. Amostra 49

3.4. Coleta de dados 50

3.4.1. O instrumento de coleta de dados 50

3.4.2. Escolha da tecnologia a ser avaliada 50

3.4.3. A coleta de dados 51

3.5. Análise dos dados 51

3.5.1. Validade e Confiabilidade 51

3.5.2. Análises Estatísticas 52

3.6. Limitações do método 53

3.6.1. Limitações relacionadas ao critério de amostragem 53

3.6.2. Limitações decorrentes da coleta de dados 53

4 Modelagem e análise de dados 54

4.1. Caracterização da amostra 54

4.2. Análises e Resultados 56

4.2.1. Avaliação do modelo de mensuração 56

4.2.2. Validade e Confiabilidade 57

4.2.3. Análise do Modelo Estrutural 62

4.2.3.1. Ajuste do Modelo Proposto 63

4.2.3.2. Teste das Hipóteses de Pesquisa 64

4.3. Discussão dos Resultados 68

4.3.1. Influência das relações de endosso em mídias sociais 69

4.3.2. Avaliação do impacto normativo e informacional 70

4.3.3. Avaliação do impacto cognitivo $\quad 70$

4.3.4. O Impacto do Narcisismo Social 71

4.3.5. Influência afetiva sobre a intenção 72

5 Conclusões 73

5.1. Resumo do Estudo 73

5.2. Conclusões 73

5.3. Implicações Gerenciais $\quad 74$ 
5.4. Limitações

5.5. Sugestões para pesquisas futuras

6 Referências Bibliográficas

Apêndice A - Questionário utilizado na pesquisa

Apêndice B - Tipos de mídias sociais 


\section{Lista de figuras}

Figura 2-1 Modelo de Lacunas, adaptado de Zeithaml e Bitner, 2011

Figura 2-2 Continuum da relação com o cliente 26

Figura 2-3 Tríade Recíproca 34

$\begin{array}{ll}\text { Figura 2-4 Modelo Conceitual Proposto } & 37\end{array}$

Figura 4-1 Modelo Conceitual Proposto com Hipóteses 63

Figura 4-2 Coeficientes Padronizados Estimados para o Modelo Proposto (** indica p-valor $<0,001 ; *$ indica p-valor $<0,05)$ 


\section{Lista de tabelas}

Tabela 3-1 Escalas e medidas operacionais para cada variável do instrumento de pesquisa

Tabela 4-1 Características da Amostra 55

Tabela 4-2 Confiabilidade, Confiabilidade Composta e AVE 59

Tabela 4-3 Cargas Fatoriais Padronizadas $\quad 60$

Tabela 4-4 Índices de Ajuste do Modelo Proposto 64

Tabela 4-5 Coeficientes Padronizados Estimados, Hipóteses e Significâncias para o Modelo Estrutural Proposto 65

Tabela 4-6 Resumo dos Resultados dos Testes de Hipóteses 68 


\section{Lista de quadros}

Quadro 2-1 As crianças e os adolescentes na era digital 32

Quadro 4-1 Matriz de Correlação entre Construtos 57

Quadro 4-2 Matriz de Validade Discriminante 62 
Invictus

Dentro da noite que me rodeia Negra como um poço de lado a lado Agradeço aos deuses que existem por minha alma indomável

Sob as garras cruéis das circunstâncias eu não tremo e nem me desespero Sob os duros golpes do acaso Minha cabeça sangra, mas continua erguida

Mais além deste lugar de lágrimas e ira, Jazem os horrores da sombra. Mas a ameaça dos anos, Me encontra e me encontrará, sem medo.

Não importa quão estreito o portão Quão repleta de castigo a sentença, Eu sou o senhor de meu destino Eu sou o capitão de minha alma.

William Ernest Henley (1849-1903) 


\section{Introdução}

As gerações atuais (Y, Z, Me...) são conhecidas como as Gerações Silenciosas pois fazem uso extensivo de mecanismos de mídias sociais e serviços de mensagem (SMS e mais recentemente Whatsapp e Facebook Messenger) em lugar de serviços de voz (HART, 2010). Tais gerações, que começam a ser responsáveis por grande parte do mercado consumidor, se sentem mais à vontade com a troca de mensagens vis-à-vis as relações diretas que normalmente ocorrem na comercialização de serviços e suporte pós-venda, facilitando a ampliação do escopo de soluções de auto-serviço e auto-atendimento para esse público. Nesse prisma, torna-se interessante entender de que forma esses novos consumidores se comportam nas mídias sociais e as relações e questões que os levam a adotar novas tecnologias e consumir novos produtos e serviços que podem trazer implicações significativas tanto para a evolução da teoria acadêmica como para gestores de empresas. No presente estudo é proposto um modelo conceitual para avaliação da intenção de adoção de uma nova tecnologia de auto-serviço, integrando relações de endosso nas mídias sociais aos efeitos moduladores que o Narcisismo Social (narcisismo nas mídias sociais) podem causar sobre a dimensão afetiva uma vez que o consumo em si não seja uma necessidade fim, mas sim um meio para se auto afirmar. Surveys online com consumidores de serviço de telefonia móvel foram analisados através de equações estruturais afim de se testar se as hipóteses criadas através de indícios de relações observados na revisão da literatura foram ou não confirmadas.

\section{1.}

\section{Problema de Pesquisa}

O termo CRM (Customer Relationship Management) foi cunhado para designar uma cultura e estratégia empresarial onde o cliente está no centro de todas as atividades da empresa. Tal foco no cliente deve ser estabelecido de maneira transversal em toda a corporação e passa pela necessidade de um 
conjunto de ferramentas automatizadas para interface com clientes, afim de manter uma relação duradoura que busque a rentabilidade no longo prazo, não somente nas transações individuais (PEPPERS e ROGERS, 2011). Uma dessas ferramentas de relacionamento com o consumidor é chamada de Serviço de Atendimento ao Consumidor (SAC), que é utilizado, na maioria das vezes, quando um cliente deseja algum tipo de suporte a um serviço e/ou produto já contratado.

Grandes empresas aplicam boa parte de seu faturamento no desenvolvimento de novas tecnologias e inovações, sem deixar de lado o controle de gastos. Toda essa inovação aliada a uma visão constante de contenção de despesas fez com que cada vez mais empresas passassem a automatizar alguns processos na sua cadeia de produção de serviços e/ou produtos. Um dos resultados dessa fusão entre inovação e redução de gastos foi a criação do conceito de autoserviço. Lovelock e Young (1979) apontam que uma das formas para as empresas poderem aumentar seus lucros é fazer com que os clientes trabalhem cada vez mais.

Durante muito tempo o SAC ficou limitado a meios como o atendimento por telefone (call-center, 0800 e 400X), extremamente caros devido a grande quantidade de funcionários responsáveis por atender o volume cada vez maior de ligações recebidas pelas empresas. Com a redução dos custos da tecnologia de reconhecimento de voz, por volta dos anos 80, com a criação da unidade de resposta audível (URA) e mais recentemente com a incorporação do e-mail e da internet (website), as empresas começaram a "terceirizar" parte do serviço de atendimento ao consumidor para o próprio consumidor (SAC3C) que passou a ter um papel importante na "navegação" dos diversos menus de atendimento e consequentemente na sua própria experiência de atendimento e resolução de problemas. Além dessa componente de terceirização, existe a questão paradoxal onde a adoção de uma tecnologia pode ao mesmo tempo trazer benefícios, como uma maior eficiência no atendimento ao consumidor, mas não ser eficaz nessa comunicação com o consumidor (MICK e FOURNIER, 1998) uma vez que não existe mais a interação humana face a face fazendo com que o consumidor fique cada vez mais distante das empresas, causando dois grandes problemas: a relação com o consumidor ficou cada vez mais impessoal, fazendo com que eventuais políticas de retenção não surtam efeito ou cheguem tarde de mais; e a perda do 
"feedback" sobre a experiência do cliente no consumo daquele serviço em sua fase pós-consumo, deixando as empresas "cegas" com relação a como a entrega do serviço e a resolução de problemas está sendo percebida por seu consumidor.

Esse mesmo desenvolvimento tecnológico que temos observado nas empresas do ponto de vista da elaboração de novos mecanismos de fabricação e entrega de serviços, também ajudou a impulsionar uma mudança cultural na sociedade de uma maneira geral que passa a ter mais acesso a informações e de maneira cada vez mais rápida (PEPPERS e ROGERS, 2011). As gerações atuais (Y, Z, Me...) fazem uso extensivo de mecanismos de mídias sociais e serviços de mensagem (SMS e mais recentemente Whatsapp) em lugar de serviços de voz (HART, 2010; HAFNER, 2009; BRANDÃO, 2006). Tais gerações, que começam a ser responsáveis por grande parte do mercado consumidor, se sentem mais à vontade com a troca de mensagens visto que a mesma é pouco intrusiva e permite uma resposta em momento mais adequado e de forma um pouco mais racional, o que é um paradoxo, visto se tratar de uma geração imediatista que também se preocupa com a velocidade das informações. Além disso existe uma componente narcisista social (narcisismo nas mídias sócias) presente nessas gerações que as tornam verdadeiros abutres no consumo de novos modelos de negócio (PAIVA, 2012; GERRA, 2014; TWENGE e CAMPBELL, 2009; BUFFARDI e CAMPBELL, 2008).

O cerne desse estudo se baseia nas relações que esse novo tipo de cliente tem com empresas de telefonia móvel. Parece que, apesar de a tecnologia ter evoluído e uma mudança sócio cultural ter ocorrido, as ferramentas e processos de CRM não evoluíram na direção do estreitamento da relação com o consumidor, mas sim na direção da redução de custos das empresas.

O presente trabalho visa estudar de que forma, a multicanalidade no serviço de atendimento ao consumidor é importante no ponto de vista do cliente final por meio da inclusão do atendimento via mídias sociais, além de avaliar os efeitos que esse tipo de mídia pode exercer no padrão de consumo de produtos/serviços especificamente criados com o auxilio dessa tecnologia (mídias sociais). Por fim, o estudo espera apresentar algumas implicações gerenciais e novos modelos de negócio que poderiam se beneficiar das conclusões desse estudo. 


\section{2.}

\section{Objetivos}

O presente estudo tem como objetivo principal entender qual o grau de influência de comunidades virtuais, com especial atenção para aquelas presentes em sites de mídias sociais, sobre a intenção de um consumidor em adotar tecnologias que utilizem SAC3C, avaliando também a possível existência de um efeito mediador de uma componente narcisa social por parte desse consumidor. Por fim, procura-se lançar luz a alguns possíveis anseios e expectativas dos consumidores quando utilizando SAC3C.

\section{3.}

\section{Questões de Pesquisa}

1. Os consumidores tem intenção de adotar uma tecnologia que "terceirize" parte das atividades para o próprio consumidor (SAC3C) via sites de mídias sociais?

2. Como fatores psicológicos dos consumidores afetam a intenção de uso de novas tecnologias que façam uso de mecanismos de SAC3C via sites de mídias sociais, diretamente e indiretamente via a atitude?

\section{4. \\ Relevância do Estudo}

Via de regra, o mercado de uma maneira geral, mais especificamente, o mercado de telecomunicações, escopo desse estudo, ainda considera as mídias tradicionais para contato com o cliente, como telefone, e-mail e sítio na internet. Com a popularização da internet, que se tornou mais acessível em termos financeiros e físicos para a população e o surgimento de uma nova geração de internautas, muito mais participativos, que exigem feedbacks constantes e que mudaram a forma como consumidores navegam na internet, os meios tradicionais de relacionamento com o consumidor se tornaram lentos e ineficientes.

No presente estudo é proposto um modelo conceitual para avaliação da intenção de adoção de uma nova tecnologia de auto-serviço, integrando relações de endosso nas mídias sociais aos efeitos mediadores que o Narcisismo Social (narcisismo nas mídias sociais) pode causar sobre a dimensão afetiva. 
Compreender melhor as razões de adoção desse tipo de tecnologia poderia ajudar empresas prestadoras de serviço e até mesmo indústrias de uma maneira geral, que existe espaço para uma nova forma de entrega de serviço abrindo novos horizontes para as empresas que se proponham a desenhar suas ofertas de maneira mais efetiva.

\section{5 . \\ Delimitações do Estudo}

Este trabalho estudou o quanto o SAC por meio das mídias sociais é importante para os clientes de operadoras de telefonia móvel brasileiras.

Diversas operadoras de telefonia móvel desenvolveram produtos e serviços com foco no mercado de jovens usuários de telefonia móvel, como as operadoras OI e TIM brasileiras e as operadoras O2 e Virgin Mobile inglesas que lançam mão de conceitos de auto serviço, auto atendimento e "gamefication" e que, por se tratarem de soluções inovadoras no mercado de telefonia móvel, permitem testar com bastante precisão a dimensão de ansiedade do modelo proposto. A pesquisa de que trata este trabalho se baseia em uma oferta de telefonia móvel pré-paga existente no mercado brasileiro chamada TIM Beta da operadora TIM Celular brasileira.

Não é objeto deste trabalho fazer um estudo epistemológico da população que faz uso das mídias sociais e de que existem traços de uma personalidade narcisista nessa população.

O trabalho também não pretende estudar, como, por que e nem quando tais pessoas se conectam nas redes sociais.

Ao final do trabalho, o autor propõem alguns modelos para implantação de tipos de CRM Social (um dos diversos canais que fazem parte do CRM) que podem jogar uma luz sobre o tema mostrando de uma forma pragmática os benefícios para as empresas de telefonia móvel que desejem implementar tais técnicas. 


\section{2 \\ Referencial Teórico}

Neste capítulo é realizada uma revisão da literatura que suporta as discussões aqui propostas.

Antes de chegar ao item final onde discute-se o modelo conceitual proposto, serão examinados alguns tópicos relacionados que formaram a base para a elaboração posterior.

Inicialmente será discutido alguns aspectos importantes sobre Marketing de Serviços com especial atenção para as tecnologias de auto-atendimento, escopo deste estudo.

Em seguida é feita uma breve analise sobre as relações de atendimento e suporte ao consumidor com foco no uso das mídias sociais como ferramental para esse tipo de atendimento.

Em uma próxima etapa são discutidas as questões psicossociais do público algo do estudo, avaliando questões sobre traços de personalidade e hábitos de uso da internet e das mídias sociais.

E por fim é apresentado um modelo conceitual para avaliação de adoção de uma tecnologia de auto-atendimento junto com as hipóteses testadas.

\section{1.}

\section{Marketing de Serviços}

Antes de discutir se e quais são os impactos da utilização do auto-serviço é necessário discorrer sobre a literatura de marketing de serviços para entender o papel do consumidor na produção e entrega do serviço fim.

Dezenas de autores já fizeram diversas considerações acerca da definição de "serviços" e seus problemas de definição. Para os propósitos desse artigo será considerado que "serviço" é executado ao invés de ser produzido e é essencialmente intangível (ZEITHAML e BITNER, 2011). 


\subsection{1.}

\section{Lacunas de Serviço}

Zeithaml e Bitner (2011) apresentam um modelo conceitual baseado nas lacunas ("gaps") existentes nos diferentes processos da prestação de serviços.

Como podemos observar na figura 2-1, a fim de melhorar a qualidade dos serviços prestados, Zeithaml e Bitner (2011) mostram que devemos estar atentos a essas barreiras de atendimento:

- Lacuna do cliente (lacuna 0): diferença entre as expectativas e as percepções do cliente. A expectativa é o padrão de referência que o cliente leva e a percepção é uma avaliação subjetiva da experiência do serviço que dependem de como ele foi presenciado;

- Lacuna da compreensão do cliente (lacuna 1): é a diferença entre aquilo que o cliente espera de um determinado serviço e como a empresa enxerga essas expectativas;

- Lacuna do projeto e dos padrões de serviço (lacuna 2): dificuldades para transferir a compreensão das expectativas dos clientes em projetos e especificações claras afim de que seus funcionários sejam capazes de entender e executar tais serviços;

- Lacuna do desempenho do serviço (lacuna 3): apesar de ter projetos e especificações claros e que atendam as expectativas do cliente, é necessário que a empresa detenha ferramentas (processos e sistemas) para executar tais serviços afim de conseguir, no mínimo, satisfazer as expectativas do cliente;

- Lacuna da comunicação (lacuna 4): falhas nessa lacuna podem levar a um aumento de expectativa do cliente, fazendo promessas excessivas por exemplo, ou a incapacidade de educar o cliente quanto ao uso correto de uma ferramenta o que poderia levar a uma insatisfação. 


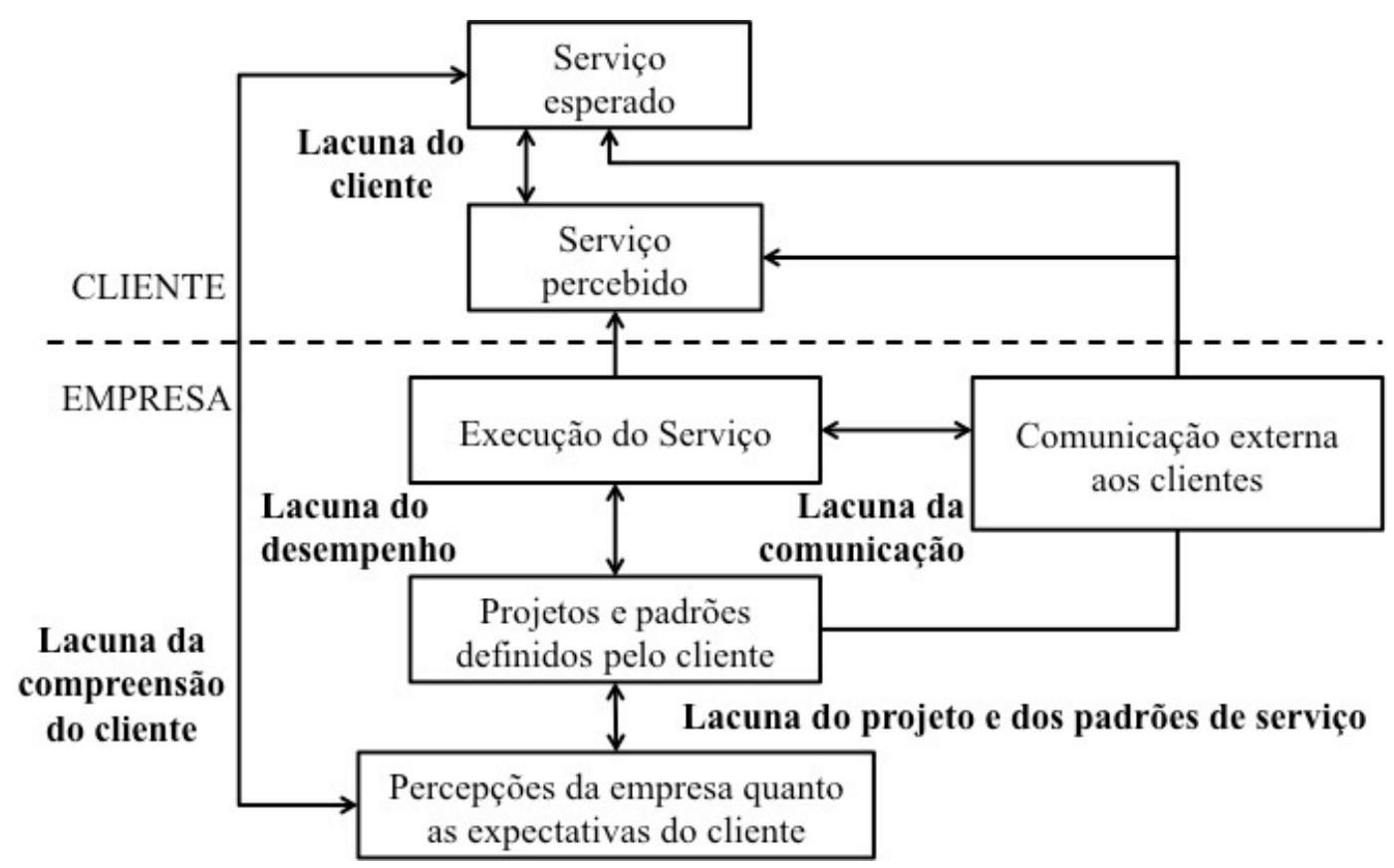

Figura 2-1 Modelo de Lacunas, adaptado de Zeithaml e Bitner, 2011

Via de regra, todas essas lacunas são responsáveis em maior ou menor nível por uma eventual insatisfação do cliente com o serviço prestado.

Apesar de a satisfação do cliente possuir uma componente emocional, tal emoção é precedida de uma componente cognitiva (CRONIN et al., 2000; BAGOZZI, 1992). Tal constructo está diretamente relacionado às expectativas do cliente com relação ao serviço prestado, logo é de suma importância um alinhamento nas expectativas do cliente e do fornecedor a fim de se atingir uma maior relação de satisfação desse consumidor.

\subsection{2.}

\section{Service Value Proposition (SVP)}

Porter (1985) já discutia a proposta de cadeia de valor como um ferramental para tentar criar mais valor para o cliente e um dos itens que aparecia nessa cadeia de valor era a dimensão de serviço. Serviço como um valor agregado ao produto afim de criar diferenciação. Vandermerwe e Rada (1988) seguem a mesma linha acrescentando que a proposta de criação de valor não se limita a enxergar mais benefícios para o cliente mas também auxilia as empresas tornando-as capazes de estabelecer uma comunicação mais duradoura com o cliente e por vezes em um momento anterior da negociação. Isso não só amplia o escopo de fatores de 
diferenciação frente ao concorrente, como também pode criar serviços tão econômicos e que são executados de forma tão exemplar, que acabam fazendo com que não valha a pena para o consumidor considerar fazer sozinho, criando uma relação de dependência.

Gummesson (2008), diz que a qualidade não advém somente de um fornecedor mas de uma série de fornecedores, entre eles o próprio consumidor. Qualidade e satisfação se unem em um conceito de valor. As empresas não produzem somente dois tipos de "outputs": produtos (coisas) ou serviços (atividades). Uma empresa produz uma proposta de valor, que é cada vez mais dependente do consumidor final para se concretizar (GUMMESSON, 2008).

Mason e Simons (2012) discutem a questão da expectativa, avaliação e comprometimento dos consumidores na proposta de entrega de valor. $\mathrm{O}$ artigo elabora sobre a importância do alinhamento entre o tipo de SVP oferecido pela empresa e aquilo que está sendo esperado e experimentado pelo consumidor. Mais ainda, o trabalho dos autores ressalta a importância de que para se identificar e reter os consumidores é necessário entender o contrato psicológico que se estabelece entre o consumidor e a empresa, buscando definir quais as motivações e necessidades para a manutenção dessa relação e os comportamentos e atitudes resultantes.

As propostas de criação de valor devem ser devidamente comunicadas aos consumidores para que os mesmo possam ter uma clara visão daquilo que esperam receber a fim de reduzir a chance de erros nas avaliações feitas pelos consumidores quanto ao que se está adquirindo (ZEITHAML e BITNER, 2011).

\subsection{3.}

\section{Lógica de Serviço Dominante (S-D Logic)}

Com o intuito de se diferenciarem e não mais competirem na base de custos ou preços, cresceu a discussão acerca do tema de servitização (VANDERMERWE e RADA, 1988; NEELY, 2008), conceito onde acrescentam-se serviços diferenciados aos produtos manufaturados.

Vargo e Lusch $(2004,2008)$ sugeriram que os avanços propostos pela subdivisão do Marketing chamada de Marketing de Serviços não deveriam se 
restringir a uma comparação em nível de produto (intangibilidade, heterogeneidade, inseparabilidade e perecividade) fazendo com que os serviços necessitassem ser sempre parecidos com produtos, mas deveriam sim ser os fundamentos de uma nova escola de pensamento, apresentando novos conceitos em uma perspectiva de serviço dominante e não mais de produto dominante, transformando os serviços em "pacotes" tangíveis (ex.: homem-hora-trabalhada) (NG, PARRY et al., 2012). Uma das premissas fundamentais ("foundational premises") de Vargo e Lusch (2004) diz que uma visão centrada no cliente é orientada ao consumidor e é relacional. Isso nos leva a uma discussão de que em um ambiente de auto-atendimento não se deve focar somente a perspectiva das empresas no sentido de uma eventual redução de custos, mesmo que a luz de uma falsa comodidade para o consumidor, mas é preciso analisar o ponto de vista do consumidor propriamente e em sendo um ambiente relacional, tal visão deveria ser de extrema importância para a empresa.

\subsection{4.}

\section{Self-Service Technologies}

As tecnologias de auto-atendimento são serviços gerados integralmente ou em parte pelos consumidores, sem o envolvimento ou a interação com os funcionários da empresa. A tecnologia aqui tem um papel muito importante. Apesar de por um lado possibilitar a prestação de serviços remotos e/ou auto atendimento, aumentando a eficácia, eficiência e até mesmo o alcance dos serviços prestados, essa mesma tecnologia acaba com as interações sociais especialmente aquelas entre funcionários e clientes.

Os clientes estão sendo mais e mais encorajados a fazer uso de ferramentas de auto atendimento (self-service). Parte disso se deve ao entendimento de que, através da tecnologia, é possível entregar um serviço de melhor qualidade, mas grande parte da razão é a de que as empresas buscam transferir para seus clientes parte dos custos (VANDERMERWE e RADA, 1988). Lovelock e Young (1979) também apontam que uma das formas para as empresas poderem aumentar seus lucros é fazer com que os clientes trabalhem cada vez mais.

Bateson (1985) sugere que alguns consumidores utilizariam soluções de auto-atendimento mesmo se eventuais incentivos como conveniência (tempo) ou 
até mesmo financeiro (desconto) fossem removidos. Diz ainda, que tais comportamentos, favoráveis ao uso do auto-atendimento, são comuns aos consumidores independentemente do serviço que está se consumindo dando indícios de que existem consumidores mais propensos a utilizar tais tipos de serviço. Uma das razões para essa propensão, ou falta dela, é o fato de que nem todos estão tecnologicamente prontos para utilizá-la.

Lin e Hsieh (2007) analisam os impactos da prontidão para a tecnologia agindo diretamente sobre a intensão de adoção e indiretamente através da satisfação. Esse trabalho resultou em três pontos chave para a adoção, ou não, de soluções de auto atendimento. Primeiro, apontam significativas influências da prontidão para a tecnologia na satisfação. Indicando claramente que quanto mais preparado tecnicamente um consumidor está, mais satisfeito ele se sentirá ao utilizar as soluções de auto-atendimento. Segundo, quanto mais preparado tecnicamente está um indivíduo, maior a propensão dele em utilizar tais soluções. E por último, mas não menos importante, quanto maior a satisfação do consumidor na utilização de ferramentas de auto atendimento maior a propensão de utilizarem novamente a solução ou indicarem para alguém. Fica claro nesse estudo a importância que as empresas devem dar ao grau de prontidão para tecnologia que seus consumidores possuem, caso contrário, mesmo com todo o suporte tecnológico, cada vez mais avançado, as empresas podem falhar em suas relações com consumidores levando a uma não adoção de tal tecnologia como também a uma insatisfação na experiência desse consumidor que, no limite, poderia leva-lo a migrar de fornecedor.

Hilton (2013) alerta para esse fato da experiência do consumidor mas sob uma ótica da lógica de serviço dominante. A empresa poderia estar implementando soluções de auto-atendimento afim de transformar o papel do consumidor de essencialmente passivo para um papel ativo, abraçando a tecnologia de auto atendimento como uma forma de co-criação de valor mas na verdade estaria simplesmente transferindo a responsabilidade pela produção dos serviços para seus clientes. Assim como Zeithaml e Bitner (2011) em sua "lacuna do cliente", Hilton (2013) também aponta para uma questão fundamental que diferencia as empresas que têm sucesso na abordagem de auto-serviço daquelas que não tem e que trata da questão da percepção do resultado do serviço entregue. 


\section{2. \\ Customer Relationship Management (CRM)}

Customer Relationship Management é um conjunto de ferramentas e processos utilizados pelas empresas na tentativa de extrair o maior valor possível de sua base de clientes através de diversas estratégias, sejam elas para aumentar o valor daqueles que já são clientes, reter clientes ou conquistar novos clientes (PEPPERS e ROGERS, 2011). Para Gummesson (2008) falar em gerenciamento da relação com o consumidor (CRM) é uma visão um pouco centrada na empresa já se a ideia é a de uma visão centrada no cliente, a empresa não deveria gerenciar nenhuma relação e sim interagir com consumidores através de relações.

\subsection{1.}

\section{Web 2.0, 2.5 ou 3.0?}

A Web 1.0 foi a própria criação e popularização da rede em si. O’Reilly (2005) foi um dos pioneiros na utilização do termo Web 2.0, apesar de o termo já existir antes disso. O termo é comumente utilizado para designar um conceito muito mais do que uma tecnologia. É um termo que trata da forma como os sites na internet passaram a ser construídos pelas empresas e como os usuários passaram a utilizá-los. Em poucas palavras é um termo que indica uma modificação no zeitgesist passando para um sistema em redes com maior participação do usuário não só em termos de criar mais conteúdo a toda a hora (não somente as empresas criam conteúdo) mas como também do sentido de uma criação coletiva ou compartilhamento da inteligência coletiva tornando a Web mais inteligente quanto mais as pessoas façam uso dela.

Alguns autores argumentam que vivemos na era da Web 3.0 (GARRIGOSSIMON et al., 2012) onde temos a massificação de ferramentas de crowdfunding e mídias sociais, entretanto para outros autores a Web 3.0 ainda é um sonho onde diferentes sistemas e tecnologias seriam capazes de convergir em uma web semântica, onde as máquinas seriam capazes de "pensar" de uma maneira mais semelhante a humana (LAMANDINI, 2011).

Para os fins desse estudo cabe somente entender que passamos por uma revolução tecnológica nesse momento que caminha para um ambiente de uso mais eficiente e inteligente dos enormes volumes de informação disponível na rede. 
Um grande exemplo desse conceito é o aplicativo de navegação israelense Waze recentemente adquirido pelo Google onde os usuários que estão com o aplicativo aberto enquanto dirigem seus carros, contribuem para carregar informações do tráfego no local em tempo real, permitindo que outros usuários possam se beneficiar daquela informação e quanto mais usuários utilizam a ferramenta, mais preciso o aplicativo fica em termos de cálculo da velocidade média nas ruas, condições de tráfego, acidentes e etc.

\subsection{2.}

\section{CRM Social (SCRM)}

Muito vem sendo escrito sobre a crescente importância das mídias sociais nas relações com os consumidores. Baseado na literatura sobre Customer Relationship Management (PEPPERS e ROGERS, 2011; WANG, 2011; GUMMESSON, 2010; WOODCOCK et al., 2011) é possível elaborar o continuum da relação do cliente com a firma (figura 2-2). O relacionamento de um consumidor com uma marca (utilizando diversas ferramentas) pode ser medido em um continuo na linha do tempo, partindo de conhecimento da marca (awareness) até, em casos extremos, a promoção do produto ou serviço feita pelos próprios consumidores em favor da marca (marketing boca-a-boca).

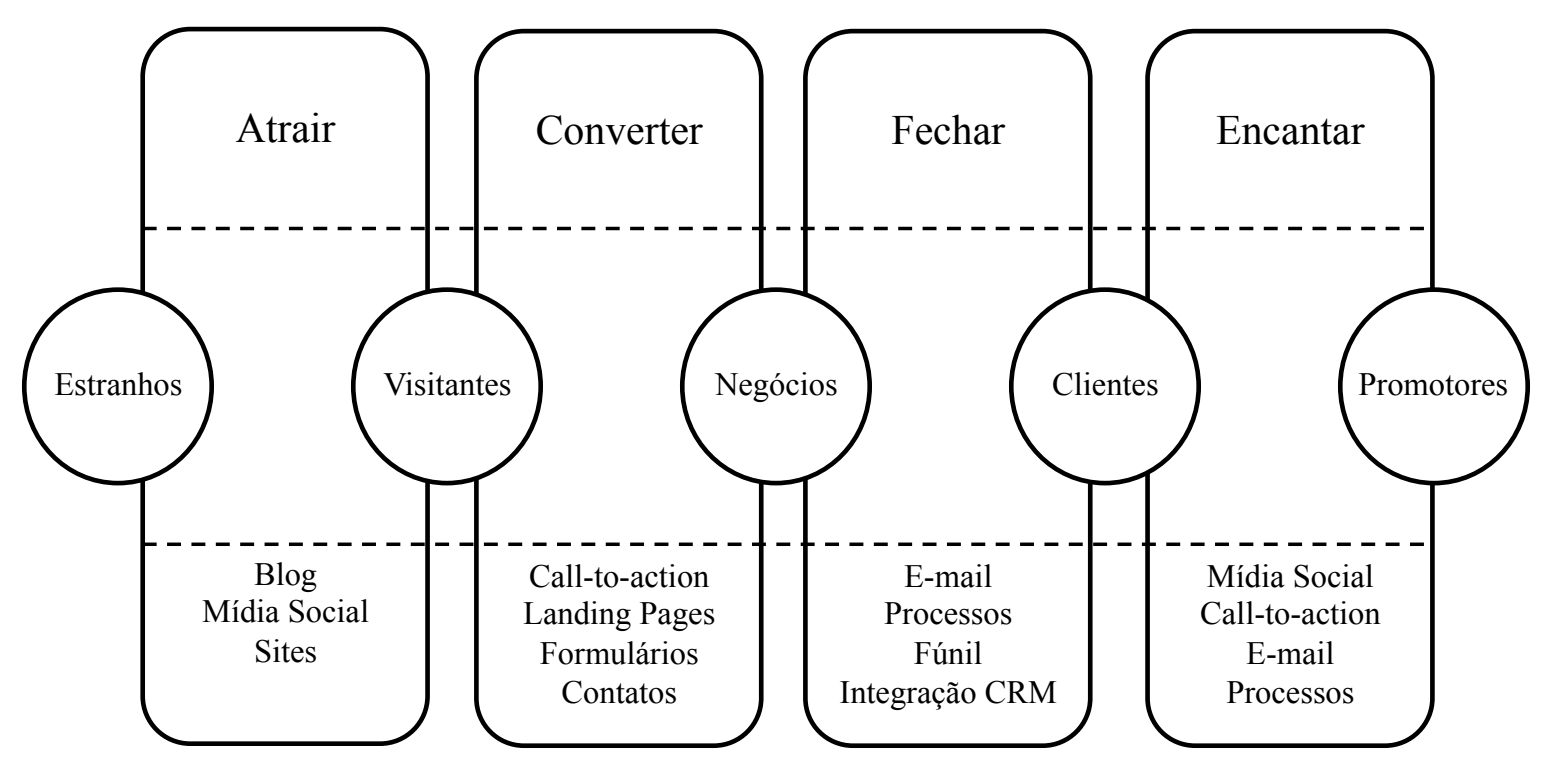

Figura 2-2 Continuum da relação com o cliente 
Os consumidores estão cada vez mais alheios às mídias comuns ( $\mathrm{TV}$, rádio, jornal) e mais sujeitos a confiar em seus pares (WOODCOCK et al., 2011). Wang (2011) chega a levantar a possibilidade de que as relações de troca do tipo B2C ou B2B2C estão fadadas a morte já que cada vez mais confiamos em nossos pares e não mais nos anúncios ou ofertas das empresas. As mídias sociais permitiram que os consumidores ficassem mais próximos daqueles considerados inovadores (ROGERS, 2005) e, como esses não possuem suas opiniões dominadas pelos vieses corporativistas, acabam se tornando mais confiáveis para os consumidores. Wang et al. (2012) mostra ainda que as comunicações com os pares são um dos fatores mais significativos na atitude do consumidor com relação a um produto.

As mídias sociais deram mais poder aos consumidores em um tipo de conversação que deixa de ser puramente unilateral, no sentido da empresa para o consumidor passando a ser bilateral (entre consumidores e empresas ou entre consumidores). Em outras palavras, as conversas sobre produtos, serviços ou marcas acontecem nas mídias sociais sem a censura das empresas forçando-as a serem mais transparentes em suas relações com os consumidores. O controle sobre as conversas está mudando das empresas para os consumidores (WOODCOCK et al., 2011).

O volume de uso desse tipo de ferramenta vem crescendo cada vez mais, em pesquisa da Nielsen (2012) 73\% das pessoas com acesso a internet utilizam mídias sociais e passam entre $20 \%$ e $30 \%$ de seus tempos de uso nesse tipo de sites, um crescimento de 76\% YoY. Um exemplo de como as mídias sociais estão se tornando cada vez mais importantes vem do trabalho de Kosinski et al. (2013) onde uma série de traços de personalidade e atributos pessoais de consumidores são previsíveis baseados simplesmente em registros digitais de comportamento (likes no Facebook).

SCRM é uma estratégia de negócio de engajamento aos consumidores através de mídias sociais com o objetivo de construir credibilidade e lealdade a marca (WOODCOCK et al., 2011).

CRM feito em meio "off-line" baseado puramente em mineração de dados em mercados com massiva quantidade de dados de vendas (serviços financeiros, telecomunicações), em essência não é diferente daquele feito em ambiente "online" utilizando softwares de monitoramente do ambiente "online" (WOODCOCK et al., 2011), o objetivo é sempre o de extrair o maior valor 
possível da base de clientes, seja ampliando a gama de serviços desses clientes, retendo os clientes mais rentáveis, ou conquistando novos clientes. O termo Social CRM foi cunhado para descrever as relações de aumento de valor para os consumidores através das mídias sociais (Apêndice B) e isso significa basicamente:

- Ajudar o cliente a interagir com a empresa, quando ele precisar, onde ele estiver, da maneira mais conveniente para o cliente;

- Fornecer a experiência pessoal que for necessária para manter o cliente engajado, informado, interessado e talvez até entretido;

- Se relacionar com cada um de maneira valorosa para ambas as partes;

- Entender cada consumidor ao longo do tempo como um único buscando adaptar o que a empresa faz, e como faz, tendo sempre o consumidor em mente.

Via de regra é grande o trabalho no sentido de utilizar as mídias sociais para branding e vendas, que sim são a atividade fim do CRM (vender mais para um mesmo cliente ou para novos) mas utilizar as mídias sociais somente com a visão de venda é subutilizar uma ferramenta (mídias sociais) capaz de fornecer dados, não somente psicográficos, mas também de como o consumidor está se sentindo, agindo ou pensando. Apesar de o CRM tradicional ajudar a gerenciar as relações com os clientes ele parece falhar na construção da confiança entre consumidores e empresas já que com as ferramentas "tradicionais" de CRM, e-mail e telefone basicamente, é mais fácil endereçar o todo e fica difícil endereçar o um (WOODCOCK et al., 2011).

As mídias sociais permitiram que as empresas, mesmo aquelas de indústrias sabidamente de mais difícil levantamento de dados (basicamente varejo), fossem capazes de endereçar consumidores individuais com um mínimo esforço se comparado aos grandes investimentos de propaganda e promoções de venda. Tais ferramentas não "falam" especificamente para um consumidor particular mas sim para todo um segmento ou na melhor das hipóteses um nicho. As mídias sociais parecem cada vez mais ser uma ferramenta poderosa no tão sonhado marketing um-a-um (WOODCOCK et al., 2011). 


\section{3.}

\section{Fatores Psicossociais}

Nesta seção procura-se discorrer sobre os fatores psicossociais dos internautas de hoje em dia.

\subsection{1. Narcisismo}

Existem quatro registros literários do mito de Narciso: Ovídio, Canon e dois de Pausanias (UBINHA e CASSORLA, 2003) e todos giram em torno de relatos amorosos de um belo jovem, de nome Narciso, que acaba sofrendo pela vingança daqueles que o amaram (Echo, Eros) sem serem correspondidos, terminando apaixonado pelo seu reflexo em um lago, definhando e morrendo já que nunca consegue ter em seus braços aquele que ama, sem saber se tratar de seu próprio reflexo e/ou sua sombra. Freud (1914) e Canevacci (1991) nos trazem a realidade de que o mito de Narciso sempre foi associado a sexualidade. Ronningstam (2005) diz que não é claro em que momento o mito de Narciso passou a representar amor próprio ou auto admiração, mas lembra que, na arte e literatura da era medieval e período Renascentista o mito já era usado para simbolizar o pecado mortal ligado a excessiva auto preocupação e auto adulação.

Freud (1914) e Lasch (1979) acreditavam que algum nível de narcisismo faz parte de todos em maior ou menor graus e nada mais é do que um mecanismo de defesa que visa proteger o ego (eu) na medida em que cria uma sensação de plenitude e capacidade de um jovem que se prepara para assumir uma série de responsabilidades ao longo da vida adulta. O problema é quando, por um distúrbio psíquico, não nos satisfazemos com a sensação de plenitude e capacidade levando ao diagnóstico de transtorno de personalidade narcisista.

De acordo com Lasch (1979) vivemos em uma cultura competitiva levada ao individualismo extremo em uma guerra de todos contra todos, a procura da felicidade até o limite da preocupação narcisista com o eu. Parte dessa cultura e sociedade vem da escola de pensamento da economia política, que postula que os indivíduos não executam suas funções laborais por prazer mas sim por um fim que é o de adquirir riqueza, ou seja, um interesse em si mesmo sem grandes 
apreços pelo outrem (SMITH, 1910). Na época em que Adam Smith escreveu The Wealth of Nations (por volta do século XVIII) não haviam grandes preocupações com o individualismo, ele até fazia sentido na medida em que os valores da sociedade ainda estavam sendo estabelecidos e era necessário que cada um garantisse sua própria sobrevivência. Para Freud (1931), a cultura se apoia sobre a repressão ao sexo e a agressividade e essa a aderência à renuncia ao prazer imposta pela sociedade e suas exigências cada vez maiores custam um preço muito alto: pressão excessiva, que gera o nervosismo, basicamente: ansiedade.

O homo economicus acabou por criar meios para que os novos narcisos não mais se submetessem tão somente a culpa mas cada vez mais à ansiedade (FREUD, 1931; LASCH 1979).

"A personalidade narcísica caracteriza-se por uma grande exigência de diversidade e pluralidade. Clama constantemente por auto-realização. Ego centrado, particularista e hedonista, o narcisista busca viver intensamente o momento, desprezando o passado e negligenciando o futuro." (SEVERIANO e ALVARO, 2006)

Severiano e Alvaro (2006) apontam as principais características dos narcisistas atuais e Twenge e Campbell (2009) mostram que vem aumentando o número de jovens com características cada vez mais narcisistas. Descobriu que os alunos dos anos 2000 tinham traços narcisistas muito mais acentuados que os jovens das três décadas anteriores. Em 2006, dois terços deles pontuaram acima da média obtida entre 1979 e 1985. Um aumento de 30\% (GUIMARAES et al., 2012). "O narcisismo pode levar ao excesso de confiança e a uma sensação fantasiosa sobre seus próprios direitos", diz Campbell (TWENGE e CAMPBELL, 2009). Os autores apontam ainda uma possível causa para esse aumento no número de jovens narcisistas, de acordo com eles, os pais da sociedade atual tratam seus filhos como se fossem da realeza, como se seus filhos fossem especiais para o resto do mundo e não somente para os próprios pais.

Guimaraes et al. (2012) trazem uma série de entrevistas e dados que comprovam que de fato a sociedade atual foi construída sob uma ótica de excesso de cuidado com a prole o que levou a uma geração mimada baseada na teoria da autoestima (pouca crítica e muito elogio). Outros estudiosos argumentam que os pais não são os únicos culpados pois a própria sociedade também ajuda na definição desses comportamentos. Em estudo de Salganik et al. (2006) surgem 
fortes evidências de que os comportamentos dos pares influenciam as escolhas dos novos usuários.

ACKERMAN et al. (2011) dizem que existem aspectos positivos do narcisismo como "extroversão, liderança e autoridade" mas também citam vários aspectos negativos que incluem: "realeza, vaidade, superioridade, tendências exibicionistas, necessidade de serem, exploração, maquiavelismo, etc...”. Pessoas que tem alto escore no narcissistic personality inventory (NPI; RASKIN e TERRY, 1988; AMES et al., 2006) necessitam sempre estar no centro das atenções, falam coisas polêmicas e inapropriadas além de buscarem a auto promoção inapropriadamente a qualquer custo. Eles irão utilizar qualquer oportunidade para se promoverem. Basta ganhar o interesse e a atenção de outros para se satisfazerem.

Carpenter (2012) leva a discussão do narcisismo para as mídias sociais aplicando o NPI em 294 estudantes e o exibicionismo se mostrou latente nesse público. Todos aqueles que tiveram uma pontuação alta no NPI, consistente com uma personalidade com traços narcisistas, tinham tendências a autopromoção e o exibicionismo. E Paiva (2012) ainda acrescenta se tratar de uma geração que exige feedbacks constantes e que, com acesso a uma tecnologia que permite certo exibicionismo, podem sugerir um aumento dos traços de comportamentos narcisista.

\subsection{2. \\ Geração Digital}

Tagliamonte e Denis (2008) dizem que os jovens tem utilizado as ferramentas de Instant Message (IM) em um ritmo sem precedentes com taxas de expansão sempre crescentes. Opinião que também é compartilhada por Anandarajan et al. (2010). Em estudo realizado pela Nielsen em 2012, as pessoas continuam a passar mais tempo em redes sociais do que qualquer outra categoria de sítios e esse tempo é maior a medida em que o usuário possua acesso a tecnologias móveis. Se considerarmos que uso de mídias sociais tem aumentado sistematicamente e que grande parte das comunicações entre pessoas nesse tipo de mídia são feitas de forma escrita (seja por envio de mensagem aberta - post na timeline, ou um tweet - ou através de mensagens privadas em ferramentas de IM 
nativos das aplicações) são claras as evidências de que existe um aumento no uso desse tipo de comunicação entre jovens. Apesar de Anandarajan et al. (2010) utilizarem o modelo TAM em sua pesquisa, que não considera a discussão sobre o quanto a prontidão para tecnologia afeta o uso da tecnologia de IM, de acordo com Prensky (2001) e Sultan e Roan (2005), os jovens podem ser considerados Nativos Digitais e portanto já nascem dominando as tecnologias digitais (EISENSTEIN, 2011).

Eisenstein (2011) argumenta que como os jovens cresceram num universo paralelo ao dos pais e de muitos de seus professores, foram construindo novos conceitos, mudando comportamentos (quadro 2-1):

Quadro 2-1 As crianças e os adolescentes na era digital

\begin{tabular}{|c|c|}
\hline Crianças e Adolescentes & Universo Digital \\
\hline $\begin{array}{c}\text { Desafiam limites e transgridem } \\
\text { regras e horários }\end{array}$ & $\begin{array}{l}\text { Tudo é sem fronteiras, sem limites } \\
\text { e sem demora e simultâneo }\end{array}$ \\
\hline Fantasias e imaginação & $\begin{array}{c}\mathrm{O} \text { anonimato garante a } \\
\text { possibilidade de mentir sobre } \\
\text { qualquer coisa }\end{array}$ \\
\hline $\begin{array}{l}\text { Todos querem ter amigos e } \\
\text { pertencer a um grupo de iguais e } \\
\text { sofrem a pressão dos amigos }\end{array}$ & $\begin{array}{l}\text { Mundos real e virtual se confundem } \\
\text { e são criados novos códigos de } \\
\text { relacionamento, aumentam os } \\
\text { contatos entre o grupo de iguais, } \\
\text { mas serão todos amigos? }\end{array}$ \\
\hline $\begin{array}{c}\text { Tornam alvos preferidos do } \\
\text { consumismo e da globalização } \\
\text { digital }\end{array}$ & $\begin{array}{c}\text { Alvo de vendas on-line e da } \\
\text { pirataria digital, acesso fácil ao } \\
\text { proibido }\end{array}$ \\
\hline $\begin{array}{l}\text { Enfrentam crises de valores com } \\
\text { seus pais e professores sobre o que } \\
\text { é "realmente" importante no aqui e } \\
\text { agora virtual }\end{array}$ & $\begin{array}{l}\text { Não existe a fiscalização e muito } \\
\text { menos valores sobre o que é } \\
\text { "virtualmente" importante, pois } \\
\text { tudo é (quase sempre) "real" }\end{array}$ \\
\hline $\begin{array}{l}\text { Procura de sua própria identidade e } \\
\text { autonomia. O nome é importante. }\end{array}$ & $\begin{array}{c}\text { Construção de uma (ou varias) } \\
\text { versão(ões) virtual da identidade. O } \\
\text { nome é substituído por senhas e } \\
\text { logins }\end{array}$ \\
\hline Crescer demora muito tempo & Tudo é rápido e imediato \\
\hline
\end{tabular}

\section{4 .}

\section{Modelo Conceitual de Adoção de Tecnologia}

No presente estudo será proposto um novo modelo conceitual para adoção de tecnologia que engloba uma perspectiva de socialização do consumo através de 
mídias sociais com a Teoria Cognitiva Social (BANDURA, 1977, 1978, 1982, 1986; COMPEAU e HIGGINS, 1995, 1999) e a Teoria da Socialização (WARD, 1974) junto com a avaliação de traços de personalidade narcisista dos consumidores. Como preambulo ao modelo proposto, serão discutidos alguns pontos que formam a base teórica para o modelo em questão.

\subsection{1.}

\section{Teoria da Aceitação de Tecnologia}

O termo technology acceptance (aceitação de tecnologia) vem do nome de um construto do modelo TAM (Technology Acceptance Model) criado na tese de doutorado de Fred Davis em 1986 que buscava entender melhor os fatores que levavam trabalhadores do laboratório da IBM em Ontário no Canadá a utilizar softwares de e-mail e planilha eletrônica. Apesar de ser um dos modelos mais adotados nessa linha de estudo que procura entender quais são os fatores que levam um determinado individuo a adotar um determinado comportamento (BENBASAT e BARKI, 2007), são diversos os trabalhos que buscam entender esse tipo de comportamento e de adoção de novas tecnologias. Na maioria das vezes tais trabalho seguem uma linha de adoção de sistemas de informação em ambientes empresariais e alguns exemplos são o modelo TAM de Davis (1986), Davis et al. (1989), o modelo UTAUT Venkatesh et al. (2003), o modelo TAM 3 de Venkatesh e Bala (2008) e poucos foram os estudos na direção de entender tais anseios do ponto de vista de um consumidor final como o modelo CAT (consumer acceptance technology de Kulviwat et al. (2007).

A Teoria Cognitiva Social (Social Cognitive Theory ou SCT) por sua vez, postula que o comportamento humano e explicado por uma tríade recíproca (figura 2-3). Uma visão de que fatores pessoais, ambientais e comportamentais influenciam uns aos outros de uma maneira bidirecional. Dessa forma, fatores do ambiente onde esse individuo esteja inserido e seu grupo de referência, ou ainda aspectos cognitivos e fatores pessoais como personalidade podem ser determinados ou determinantes uns dos outros. 


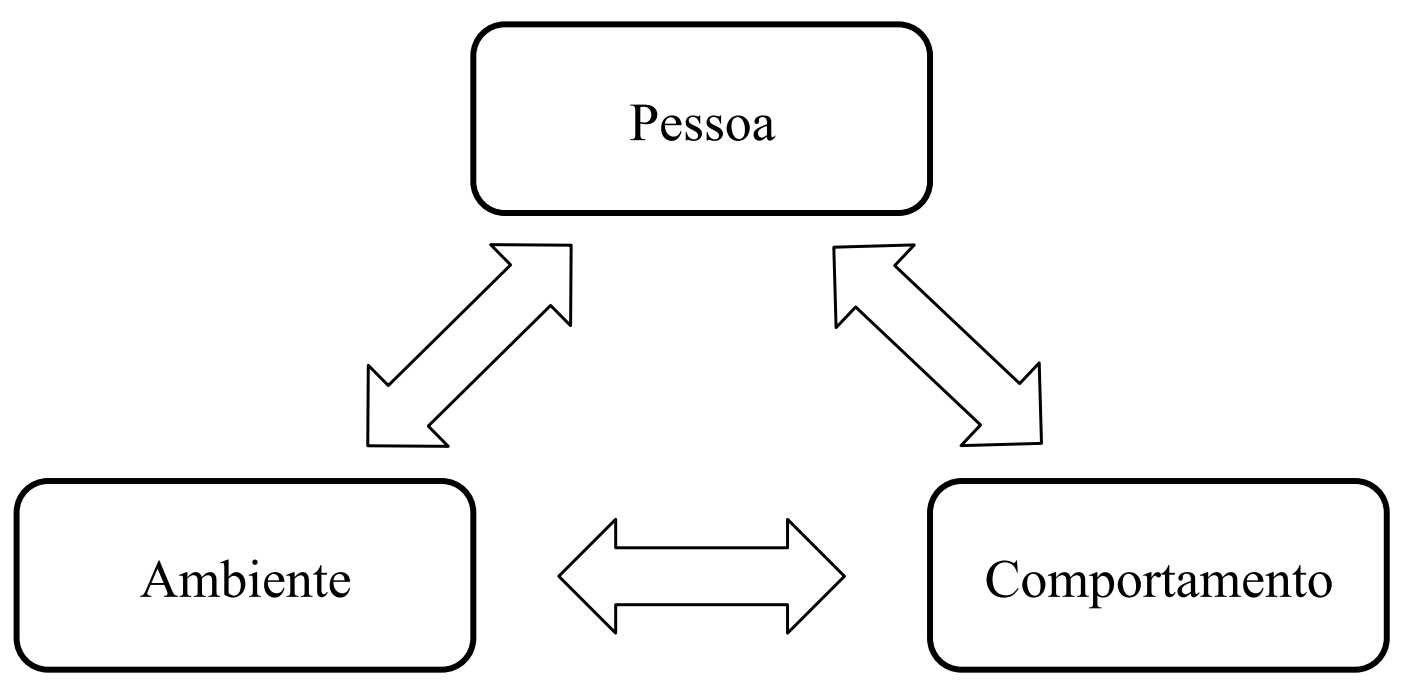

Figura 2-3 Tríade Recíproca

De acordo com Bandura são duas as principais forças cognitivas que afetam o comportamento: avaliação do resultado e auto-eficácia. As pessoas estão mais susceptíveis a adotar um determinado comportamento se acreditarem que aquele comportamento irá culminar em um resultado positivo do que um comportamento que não vá trazer nenhuma consequência positiva (avaliação de resultado). E por fim, a avaliação do próprio individuo de sua habilidade para executar um determinado comportamento também influencia a probabilidade de ele adotar tal comportamento. Essa teoria da auto-eficácia é uma das teorias fundamentais que Davis (1986, 1989) utilizou para definir seu construto de facilidade de uso percebida que é a grau de avaliação da capacidade do individuo em realizar tal atividade, enquanto a dimensão de avaliação do resultado (outcome) do trabalho de Bandura (1982) é considerada por Davis $(1986,1989)$ como similar a utilidade percebida.

\subsection{2.}

\section{Teoria da Socialização entre Consumidores}

Em seu trabalho sobre Difusão de Inovações Rogers (2005) elenca cinco passos do processos de difusão de inovações. O primeiro passo é justamente o do conhecimento. Um individuo precisa ser exposto às mensagens que comunicam uma determinada inovação (propaganda p. ex.) ou à própria inovação em si para que ele possa avaliar a adoção ou não de tal inovação. 
Ward et al. (1974) mostram que os indivíduos não tomam decisões independentemente mas sofrem interferências cognitivas, comportamentais e atitudinais de seus pares como mostrado no trabalho de Salganik et al. (2006) sobre compartilhamento de musicas na internet ratificando a teoria do aprendizado social e do desenvolvimento cognitivo. $\mathrm{Na}$ perspectiva do desenvolvimento cognitivo a questão da socialização é função da qualidade dos estágios de desenvolvimento cognitivo em que o individuo está inserido já na teoria do aprendizado social foca-se mais no aspecto ambiental em que esse individuo está inserido, transferindo normas, valores e comportamentos para o jovem (MOSCHIS e CHURCHILL, 1978). De Gregorio e Sung (2010) foram além e mostraram que a influência do grupo de amigos e conhecidos era o maior preditor das atitudes e comportamentos com relação a merchandising tie in/product placement.

Além disso, com a advento das mídias sociais foi possível a criação de um espaço virtual de comunicação facilitando ainda mais as trocas de informação os tornando agentes importantes na socialização entre consumidores (KOHLER et al. 2011; LUEG e FINNEY, 2007; LUEG et al. 2006; MURATORE, 2008; ZHANG e DAUGHERTY, 2009).

As mídias sociais fornecem pelo menos três condições que facilitam a socialização entre os pares no meio online: uma ferramenta de socialização simples e conveniente (MURATORE, 2008), mais consumidores acessam as mídias sociais em busca de informações sobre produtos e decisões de consumo (LUEG et al. 2006) e facilitam o processo de transferência de conhecimento e informação pois estão populadas com diversos agentes de socialização como amigos, conhecidos ou personalidades fornecendo grandes quantidades de informação e de uma maneira bastante ágil (GERSHOFF e JOHAR, 2006; LIN e YU, 2006; TAYLOR, LEWIN e STRUTTON, 2011; AHUJA e GALVIN, 2003).

A literatura de socialização entre consumidores aponta que os pares (amigos, conhecidos) são o primeiros agentes de socialização além da família (KOHLER et al. 2011; MOSCHIS e CHURCHILL, 1978; SHIM, 1996). Consumidores interagem com os pares para falar sobre padrões de consumo que acabam por influenciar sua atitudes com relação a produtos e serviços (CHURCHILL e MOSCHIS, 1979; MUKHOPADHYAY e YEUNG, 2010). 


\subsection{3.}

\section{Difusão de Inovações}

Rogers (2005) chama esses agentes de socialização de agentes de mudança (change agents) mas também aponta a importância que tais agentes possuem, não somente na fase de conhecimento de uma inovação, mas ao longo de todo o processo de inovação. São cinco os passos dentro do processo de decisão de inovação de acordo com Rogers (2005):

$$
\begin{aligned}
& 1 \text { - Conhecimento } \\
& 2 \text { - Persuasão } \\
& 3 \text { - Decisão } \\
& 4 \text { - Implementação } \\
& 5 \text { - Confirmação }
\end{aligned}
$$

Teoricamente um individuo só prestaria atenção, ou tomaria conhecimento das mensagens sobre uma determinada inovação se ele percebesse a necessidade de utilizar aquela inovação e mesmo que esse individuo fosse exposto a tal mensagem sobre uma nova inovação, essa exposição não teria grandes efeitos a não ser que fosse percebida como relevante para as necessidades desse individuo e fosse consistente com as atitudes e crenças desse individuo (HASSINGER, 1959 apud ROGERS, 2005). Trata-se de uma questão de percepção seletiva ou exposição seletiva onde um individuo tende a interpretar as mensagens de acordo com suas atitudes e crenças. De acordo com Rogers (2005), a necessidade é um estado onde os desejos do individuo superam a sua condição atual. Um individuo pode desenvolver uma necessidade, ou desejo, caso tome conhecimento sobre uma inovação. Portanto os agentes de mudança (p. ex. pares nas mídias sociais) podem criar necessidades em outros indivíduos.

\subsection{4. \\ Modelo Conceitual Proposto}

Utilizando as bases das teorias da socialização, de adoção de tecnologia e difusão de inovações, na figura 2-4 é apresentado o modelo conceitual proposto para esse estudo composto de antecedentes, processos, análise atitudinal e cognitiva, personalidade e resultados. 


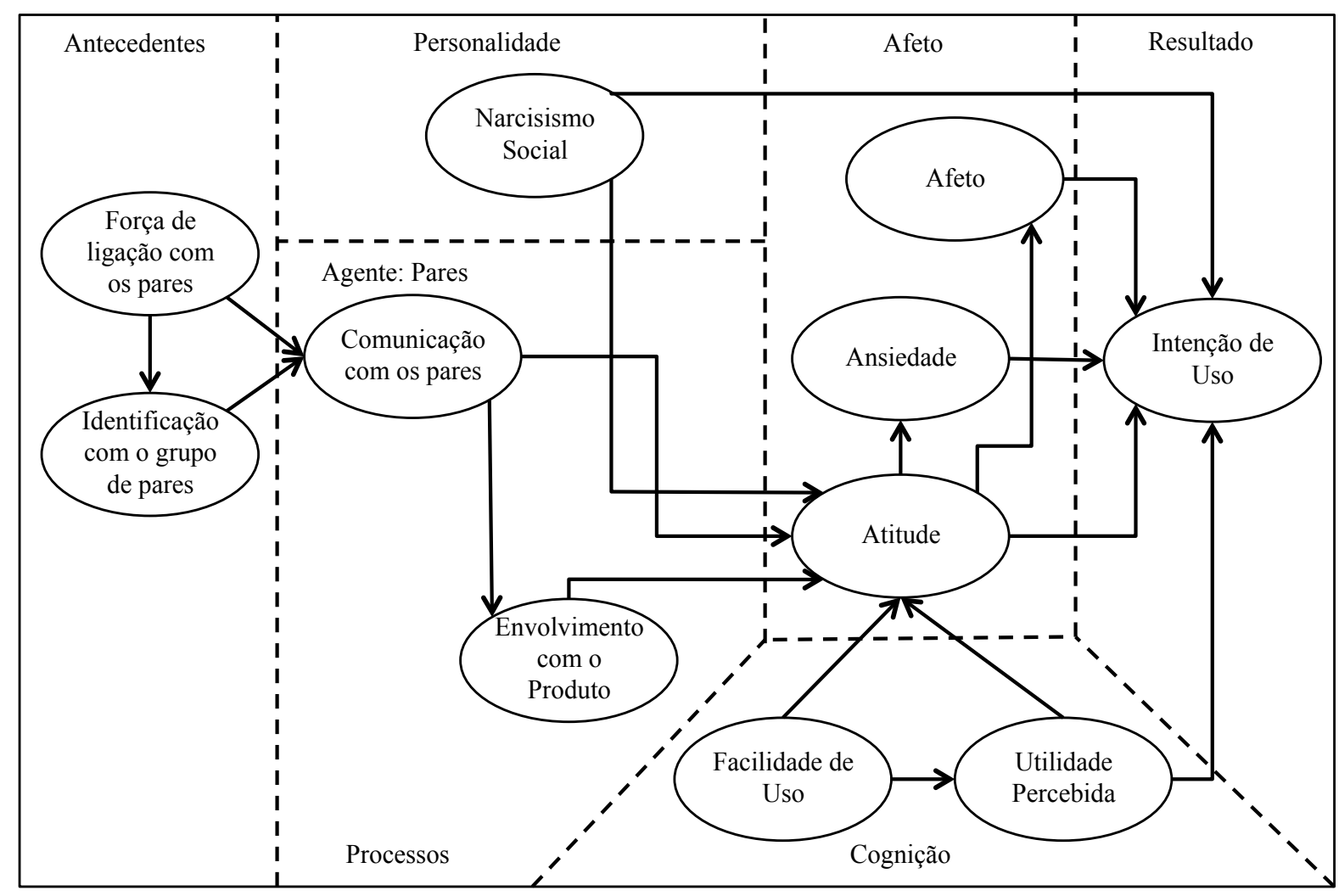

Figura 2-4 Modelo Conceitual Proposto

Força de ligação com os pares: é definido como sendo o grau em que uma pessoa está disposta a manter alguma relação com outros pares através de uma mídia social. De acordo com De Bruyn e Lilien (2008) quanto mais fortes forem essas ligações maiores as chances de transferência de conhecimento e maiores as influências nos receptores.

Além disso, a ligação entre um individuo e seus pares precede e contribui positivamente para a identificação daquele individuo como pertencente ao grupo (WANG et al., 2012; ALGESHEIMER et al., 2005).

Identificação com o grupo de pares: é a percepção de como o individuo se percebe como parte integrante daquele grupo ou comunidade. Em contraste com a percepção de uma identidade única, esse construto procura explicar o grau em que esse individuo se enxerga como parte de uma identidade coletiva ou compartilhada levando a questões de como: "Eu me vejo como parte desse grupo". Quanto maior a identificação com o grupo, mais susceptível um individuo está em concordar com as normas, tradições, rituais e objetivos daquela comunidade em detrimento de seu objetivo pessoal e portanto maior a chance de 
se estabelecer uma comunicação mais harmoniosa entre esses pares (ALGESHEIMER et al., 2005).

Comunicação com os pares: a conversa que se estabelece entre os pares pode ser capaz de trazer influências normativas e informacionais (BEARDEN, NETEMEYER e TELL, 1989). A influencia normativa pode levar um individuo que queira participar de um determinado grupo a alterar suas atitudes e comportamentos a fim de fazer com que eles se aproximem dos padrões e normas daquele grupo. Membros de grupos de sites de mídias sociais sofrem pressões de conformidade quando realizam decisões de compra (WANG et al., 2012). A influência informativa faz com que as pessoas busquem informações sobre um determinado assunto através de seus pares podendo buscar ativamente essa informação ou aprendendo apenas observando o comportamento desses pares e as mídias sociais auxiliam nessa troca de informações já que o custo para se ter acesso a tal informação é muito baixo ou inexistente (WANG et al., 2012). Através dos pares como agentes de socialização, os indivíduos são comunicados a cerca das normas daquele grupo (influência normativa) e também buscam informações a cerca daquele produto ou serviço uma vez que trata-se de um padrão dentro do grupo (influência informativa). Quando sob influência informativa, os indivíduos recorrem aos aprendizados que tiveram através de seus pares ou através da observação daqueles para determinar o envolvimento com determinando produto ou serviço o que poderia em último caso afetar também as suas atitudes com aquele produto ou serviço. Quanto mais informação esses indivíduos recebem, maior o envolvimento com determinado produto ou serviço e consequentemente maiores as chances de desenvolver atitudes positivas com aquele produto ou serviço (KIM, HALEY e KOO, 2009; WANG et al., 2012).

H1: A força de ligação com os pares tem um efeito direto e positivo com a identificação com o grupo de pares.

H2: A força de ligação com os pares tem um efeito direto e positivo na comunicação entre os pares.

H3: A identificação com o grupo de pares tem um efeito direto e positivo associado com a comunicação com os pares. 
Envolvimento com o produto: é um construto psicológico e está relacionado com a relevância que o individuo percebe naquele produto ou serviço, baseado em suas necessidades, valores e interesses (ZAICHKOWSKY, 1985). O envolvimento do consumidor com determinado produto ou serviço motiva reações dos consumidores de tal forma que consumidores com alto envolvimento tendem a estar mais interessados e mais inclinados a adquirir tal produto ou serviço (KARMARKAR e TORMALA, 2010; KIM, HALEY e KOO, 2009).

\section{H4: O envolvimento com o produto afeta direta e positivamente a} atitude com relação ao produto ou serviço.

Afeto e Ansiedade: representam a resposta afetiva dos indivíduos em utilizarem ferramentas de auto-atendimento em telefonia móvel. O afeto de um individuo ou quanto esse individuo gosta de algo pode exercer uma forte influência sobre suas ações (BANDURA, 1986) e representa a parcela positiva enquanto a Ansiedade representa a parcela negativa, as sensações de apreensão ou ansiedade que o individuo sente ao utilizar soluções de auto-atendimento (COMPEAU e HIGGINS, 1999).

Atitude com relação ao produto: consumidores aprendem atitudes e comportamentos através de mensagens escritas que seus pares compartilham (LUEG e FINNEY, 2007). A comunicação com os pares está associada com o aprendizado sobre consumo, marcas preferidas, envolvimento ou intenção de compra/uso. O comportamento do consumidor e suas atitudes tendem a serem influenciadas pelos aprendizados adquiridos através dos agentes de socialização, nesse caso, pares nas mídias sociais (WANG et al., 2012). Uma atitude é uma predisposição aprendida para um comportamento consistente favorável, ou não, com relação a algo (ASSAEL, 1995; SCHIFFMAN e KANUK, 1997).

H5: A comunicação entre os pares afeta direta e positivamente a atitude com relação ao produto ou serviço.

H6: A comunicação entre os pares afeta direta e positivamente o envolvimento com o produto ou serviço.

H7: A atitude com relação ao produto afeta direta e positivamente o afeto. 
H8: A atitude com relação ao produto afeta direta e negativamente a ansiedade.

Narcisismo social: é um constructo psicológico que mede o quão narcisista é a personalidade de uma pessoa.

Raskin e Terry (1988) apontam algumas características dos narcisistas: autoridade, exibicionismo, superioridade, título (entitlement), exploração, auto suficiência e vaidade. Indivíduos com grandes pontuações nesses itens tenderão a procurar ganhar a atenção da maior audiência possível, com o maior número de amigos possível (eventualmente até estranhos), postar updates de status e a maior quantidade de conteúdo possível, com alterações sistemáticas no perfil justamente para focar a atenção nele mesmo (CARPENTER, 2012). De acordo com Paiva (2012) os participantes do Facebook procuram exibir uma "persona midiática" o mais próxima possível da perfeição e em conformidade com as normas daquele grupo do qual se fazem parte dentro das mídias sociais (WANG et al., 2012). Wang et al. (2012) ainda acrescentam que que uma eventual "pressão" de seus pares poderia motivar os consumidores a utilizarem ou comprarem um produto que poderia trazer uma recompensa como por exemplo uma relação mais próxima com seus pares o que no ponto de vista narcisista poderia seu um fator extra no sentido de se explicar uma maior relação entre o narcisismo social e as dimensões afetivas.

De acordo com a literatura visitada, existem indícios que apontam para uma influencia da personalidade narcisista do individuo em seu comportamento:

\section{H9: O narcisismo social afeta direta e positivamente a atitude.}

H10: O narcisismo social afeta direta e positivamente a intenção de uso.

Utilidade percebida e Facilidade de uso: utilidade percebida é o grau com que uma pessoa acredita que a utilização de um determinado sistema irá aumentar a sua performance na execução de suas atividades e facilidade de uso percebida é o grau com que um individuo acredita que a utilização de um sistema dispenda pouco esforço. São sugeridos como os dois constructos mais significativos na previsão de um utilização de um sistema: utilidade percebida é o conceito que determina que as pessoas tendem a usar, ou não, uma determinada solução se 
entenderem que aquilo vai ajuda-los a cumprir suas tarefas mais facilmente, e facilidade de uso é a dimensão que mede o quão simples é utilizar aquela solução (DAVIS, 1986, 1989). Lembrando Hassinger (1959 apud ROGERS, 2005) um individuo só tomaria conhecimento ou seria influenciado por uma mensagem se a inovação fosse percebida como relevante para as necessidades dele e fosse consistente com as atitudes e crenças desse individuo. Para Rogers (2005) durantes as fases de Persuasão e Decisão é o momento em que o individuo "mede" as vantagens relativas de uma determinada inovação e é quando ele opta por adotar ou não tal inovação. Essa "medição" sobre a vantagem relativa da inovação é exatamente o que os constructos de facilidade de uso e utilidade percebida oriundos do modelo TAM de Davis (1986, 1989), e utilizados aqui, medem. Dessa forma, de acordo com a literatura sobre TAM de Davis (1986, 1989) é postulado que:

H11: Facilidade de uso tem um efeito direto e positivo sobre utilidade percebida.

H12: Facilidade de uso tem um efeito direto e positivo sobre atitude com relação ao produto.

H13: Utilidade percebida tem um efeito direto e positivo sobre atitude com relação ao produto.

Intensão de uso: são indicadores que buscam explicar se um consumidor possui e manterão relações positivas com a empresa (LIN et al., 2007). Para Zeithaml et al. (1996) alguns comportamentos são indicativos de que um consumidor está aumentando os seus laços com as empresas prestadoras de serviço: quando elogiam a empresa, expressam preferência frente a um concorrente, recomendam a empresam ou o serviço para outros, aumentam o volume de compras, aceitam pagar preços premium ou permanecem leais as marcas e serviços, no fundo os consumidores estão expressando sua avaliação positiva com relação aquele produto ou comportamento.

Davis et al. (1989) argumenta que as pessoas tendem a formar intenções favoráveis a determinados comportamentos pois acreditam que que tal comportamento levará a algum tipo de vantagem em sua performance. Essa avaliação é medida pelo construto de utilidade percebida e, para Davis et al. 
(1989), a relação entre utilidade percebida e intenção de uso é mormente explicada por essa componente cognitiva apesar de o próprio autor reconhecer a existência de uma componente afetiva influenciando a intenção de uso.

H14: O afeto tem um efeito direto e positivo sobre a intensão de uso.

H15: A ansiedade tem um efeito direto e negativo sobre a intensão de uso.

H16: A atitude com relação ao produto tem um efeito direto e positivo sobre a intensão de uso.

H17: Utilidade percebida tem um efeito direto e positivo sobre a intensão de uso. 


\section{3 \\ Metodologia da Pesquisa}

Nesse capítulo é apresentada a metodologia de pesquisa utilizada neste estudo, incluindo instrumento, escalas e variáveis adotadas, além dos tipos de análises feitas na amostra.

\section{1.}

\section{Tipo de Pesquisa}

Em um projeto de levantamento é possível dar um valor quantitativo de determinadas atitutes ou tendências. Como o objetivo da pesquisa é entender o comportamento de jovens usuários de telefonia móvel na adoção de novas tecnologias em mídias sociais, optou-se pelo survey online na tentativa de fazer inferências sobre a população a partir de uma amostra (CRESWELL, 2010).

Ultimamente a pesquisa online tem aumentado em popularidade por diversas razões. Apesar de Schaefer e Dillman (1998) argumentarem que a proporção de casas com acesso a internet ainda é muito pequena para aplicar surveys online, em casos específicos a penetração do acesso a internet aumenta consideravelmente e é exatamente esse o caso que temos nesse estudo: jovens consumidores brasileiros, usuários de telefonia móvel e mídias sociais.

Jankowski e Van Selm (2006) nos trazem diversas razões para o uso de surveys online. O objeto do estudo em si, características específicas da população e a atratividade que esse tipo de survey tem sob grupos particulares (idade), Beebe e al (1997) sugerem que o computador poderia ter uma relevância especial no grupo de jovens.

Além disso a qualidade da informação coletada por surveys online é similar àquelas efetuadas por meio de telefone com a benesse de eliminar o viés do entrevistador, reduzir erros de digitação (desde que o questionários seja desenvolvido com questões fechadas) e conveniência para o entrevistado levando 
a um número maior de respostas (CODERRE, MATHIEU e ST-LAURENT, 2004 e JANKOWSKI e VAN SELM, 2006).

\section{2. \\ Operacionalização das variáveis}

No presente trabalho foi proposto um novo modelo conceitual para o estudo de adoção de tecnologia que parte da Teoria Cognitiva Social (BANDURA, 1977; 1978; 1982; 1986), integrando relações de endosso nas mídias sociais aos efeitos que o Narcisismo Social (narcisismo nas mídias sociais) podem causar sobre a dimensão afetiva uma vez que o consumo em si não seja uma necessidade fim, mas sim um meio para se auto afirmar.

A fim de focar os resultados nas novas hipóteses testadas, optou-se por seguir com a utilização de escalas existentes e já extensamente utilizadas. Desta forma, foram utilizadas as seguintes escalas:

- Força de ligação com os pares: escala de De Bruyn e Lilien (2008), composta por 4 itens;

- Identificação com o grupo de pares: escala de Algesheimer et al. 2005, composta por 5 itens;

- Comunicação com os pares: escala original de Moschis and Churchill (1978) adaptada por Wang et al. (2012), composta por 5 itens;

- Afeto: escala de Compeau Higgins (1999), composta por 5 itens;

- Ansiedade: escala de Compeau Higgins (1999), composta por 4 itens;

- Utilidade Percebida: escala de Davis (1989a) e Davis et al. (1989b), composta por 5 itens;

- Facilidade de uso percebida: escala de Davis (1989a) e Davis et al. (1989b), composta por 6 itens;

- Intenção de uso: escala original de Zeithaml et al. (1996) adaptada por Cronin et al. (2000) e Lin et al. (2007), composta por 3 itens;

- Envolvimento com o produto: escala de Zaichkowsky (1985), composta por 4 itens; 
- Atitude com relação ao produto: escala de Crites et al. (1994), composta por 3 itens;

- Narcisismo Social: escala de Ames et al. (2006), composta por 16 itens.

Com isso, o survey online, formado pelas as escalas apresentadas, possui um total de 60 itens, sem contar 11 relativos à categorização e demografia dos respondentes. O Apêndice A apresenta o questionário completo, com todas as escalas traduzidas segundo o procedimento descrito a seguir.

\subsection{1.}

\section{Definição operacional das variáveis}

A tabela 3-1 apresenta as definições das escalas utilizadas e as correspondentes questões aplicadas no questionário aplicado (Apêndice A).

Tabela 3-1 Escalas e medidas operacionais para cada variável do instrumento de pesquisa

\begin{tabular}{|c|c|}
\hline Construto & Tipo de escala e medidas operacionais \\
\hline \multirow[t]{2}{*}{$\begin{array}{l}\text { Força de ligação com os pares } \\
\text { (TSP) }\end{array}$} & $\begin{array}{l}\text { Escala Likert de } 5 \text { pontos (discordo fortemente - } \\
\text { concordo fortemente), adaptação para português } \\
\text { da escala de De Bruyn e Lilien (2008) }\end{array}$ \\
\hline & Apêndice A, questão 1 , itens $1,2,3,4$ \\
\hline \multirow[t]{2}{*}{$\begin{array}{l}\text { Identificação com o grupo de } \\
\text { pares IPG) }\end{array}$} & $\begin{array}{l}\text { Escala Likert de } 5 \text { pontos (discordo fortemente - } \\
\text { concordo fortemente), adaptação para português } \\
\text { da escala de Algesheimer et al. (2005) }\end{array}$ \\
\hline & Apêndice A, questão 2 , itens $1,2,3,4,5$ \\
\hline \multirow[t]{2}{*}{$\begin{array}{l}\text { Comunicação com os pares } \\
\text { (COM) }\end{array}$} & $\begin{array}{l}\text { Escala Likert de } 5 \text { pontos (discordo fortemente - } \\
\text { concordo fortemente), adaptação para português } \\
\text { da escala de Wang et al. (2012) }\end{array}$ \\
\hline & Apêndice A, questão 3 , itens $1,2,3,4,5$ \\
\hline \multirow[t]{2}{*}{ Afeto (AFE) } & $\begin{array}{l}\text { Escala Likert de } 5 \text { pontos (discordo fortemente - } \\
\text { concordo fortemente), adaptação para português } \\
\text { da escala de Compeau e Higgins (1999) }\end{array}$ \\
\hline & Apêndice A, questão 4 , itens $1,2,3,4,5$ \\
\hline
\end{tabular}




\begin{tabular}{|c|c|}
\hline \multirow[t]{2}{*}{ Ansiedade (ANS) } & $\begin{array}{l}\text { Escala Likert de } 5 \text { pontos (discordo fortemente - } \\
\text { concordo fortemente), adaptação para português } \\
\text { da escala de Compeau e Higgins (1999) }\end{array}$ \\
\hline & Apêndice A, questão 4 , itens $6,7,8,9$ \\
\hline Construto & Tipo de escala e medidas operacionais \\
\hline \multirow[t]{2}{*}{ Utilidade Percebida (UP) } & $\begin{array}{l}\text { Escala Likert de } 5 \text { pontos (discordo fortemente - } \\
\text { concordo fortemente), adaptação para português } \\
\text { da escala de Davis (1989a) e Davis et al. (1989b) }\end{array}$ \\
\hline & Apêndice A, questão 5 , itens $1,2,3,4,5$ \\
\hline \multirow[t]{2}{*}{$\begin{array}{l}\text { Facilidade de uso percebida } \\
\text { (FUP) }\end{array}$} & $\begin{array}{l}\text { Escala Likert de } 5 \text { pontos (discordo fortemente - } \\
\text { concordo fortemente), adaptação para português } \\
\text { da escala de Davis (1989a) e Davis et al. (1989b) }\end{array}$ \\
\hline & Apêndice A, questão 5, itens $6,7,8,9,10,11$ \\
\hline \multirow[t]{2}{*}{ Intenção de uso (IU) } & $\begin{array}{l}\text { Escala Likert de } 5 \text { pontos (discordo fortemente - } \\
\text { concordo fortemente), adaptação para português } \\
\text { da escala de Cronin et al. (2000) }\end{array}$ \\
\hline & Apêndice A, questão 6, itens $1,2,3$ \\
\hline \multirow[t]{2}{*}{$\begin{array}{l}\text { Envolvimento com o produto } \\
\text { (EP) }\end{array}$} & $\begin{array}{l}\text { Escala de diferencial semântico com } 5 \text { pontos, } \\
\text { adaptação para português da escala de } \\
\text { Zaichkowsky (1985) }\end{array}$ \\
\hline & Apêndice A, questão 7, itens $1,2,3,4$ \\
\hline \multirow[t]{2}{*}{$\begin{array}{l}\text { Atitude com relação ao produto } \\
\text { (ATT) }\end{array}$} & $\begin{array}{l}\text { Escala de diferencial semântico com } 5 \text { pontos, } \\
\text { adaptação para português da escala de Crites et } \\
\text { al. (1994) }\end{array}$ \\
\hline & Apêndice A, questão 8 , itens $1,2,3$ \\
\hline \multirow[t]{2}{*}{ Narcisismo Social (NS) } & $\begin{array}{l}\text { Escala de diferencial semântico com } 5 \text { pontos, } \\
\text { adaptação para português da escala de Ames et } \\
\text { al. (2006) }\end{array}$ \\
\hline & $\begin{array}{l}\text { Apêndice A, questão } 9 \text {, itens } 1,2,3,4,5,6,7,8,9 \text {, } \\
10,11,12,13,14,15,16\end{array}$ \\
\hline Variáveis demográficas & Escala categórica \\
\hline Idade & Apêndice A, questão 10, item 1: variável contínua \\
\hline Sexo & Apêndice A, questão 11, item 1:masculino, feminino \\
\hline Possui smartphone & Apêndice A, questão 12, item 1: sim, não \\
\hline Faz uso de redes sociais & Apêndice A, questão 13, item 1: sim, não \\
\hline $\begin{array}{l}\text { Utilizou soluções de auto- } \\
\text { atendimento }\end{array}$ & Apêndice A, questão 14, item 1: sim, não \\
\hline Estado Civil & $\begin{array}{l}\text { Apêndice A, questão } 15 \text {, item 1: solteiro(a), } \\
\text { casado(a), separado(a)/divorciado(a), viúvo(a) }\end{array}$ \\
\hline
\end{tabular}




\begin{tabular}{|c|c|}
\hline Renda Familiar & $\begin{array}{l}\text { Apêndice A, questão 16, item 1: “Abaixo de } 1000 \\
\text { reais", "de } 1000 \text { a } 2000 \text { reais", "de } 2000 \text { a } 3500 \\
\text { reais", "de } 3500 \text { a } 6000 \text { reais", "de } 6000 \text { a } 10000 \\
\text { reais", "Acima de } 10000 \text { reais" }\end{array}$ \\
\hline Construto & Tipo de escala e medidas operacionais \\
\hline Nível de Escolaridade & $\begin{array}{l}\text { Apêndice A, questão 17, item 1: Ensino } \\
\text { Fundamental (1o. Grau) interrompido, Ensino } \\
\text { Fundamental (1o. Grau) cursando, Ensino } \\
\text { Fundamental (1o. Grau) completo, Ensino Médio } \\
\text { (2o. Grau) interrompido, Ensino Médio (2o. Grau) } \\
\text { cursando, Ensino Médio (2o. Grau) } \\
\text { Profissionalizante cursando, Ensino Médio (2o. } \\
\text { Grau) completo, Ensino Médio (2o. Grau) } \\
\text { Profissionalizante completo, Formação Superior } \\
\text { interrompida, Formação Superior cursando, } \\
\text { Formação Superior completa, Pós-graduação no } \\
\text { nível Especialização, Pós-graduação no nível } \\
\text { Mestrado, Pós-graduação no nível Doutorado }\end{array}$ \\
\hline Operadora de Telefonia Móvel & $\begin{array}{l}\text { Apêndice A, questão 18, item 1: TIM, Vivo, Claro, } \\
\text { OI, Sercomtel, CTBC, Nextel }\end{array}$ \\
\hline Tipo de Plano & $\begin{array}{l}\text { Apêndice A, questão 19, item 1: Pré-pago, Pós-pago, } \\
\text { Outros }\end{array}$ \\
\hline Nome do Plano & $\begin{array}{l}\text { Apêndice A, questão 20, item 1: TIM beta, Oi } \\
\text { Galera, Outros }\end{array}$ \\
\hline
\end{tabular}

\subsection{2.}

Procedimentos de tradução e adaptação das escalas utilizadas

Todas as escalas utilizadas neste estudo foram originalmente elaboradas para a língua inglesa. Mullen (1995) e Douglas e Craig (1983) propõem que as equivalências de escala cumpram com três parâmetros: calibragem, tradução e equivalência métrica. Para os propósitos deste estudo somente foram necessárias a tradução e adaptação das escalas para a língua portuguesa a fim de permitir que o questionário fosse aplicado aos consumidores brasileiros. Dois tradutores diferentes fizeram a tradução das escalas originais em inglês para o português e uma retradução para o inglês (back translation) foi feita por outros dois tradutores diferentes dos originais com o intuito de garantir a maior equivalência possível na tradução final para o português, preservando os significados das escalas em português quando comparados as originais em inglês (SPERBER, 2004). As 
versões traduzidas foram analisadas e comparadas por dois especialistas no tema (pesquisadores de comportamento do consumidor, inovação e marketing online) e fluentes na língua inglesa, efetuando-se ajustes finos no documento final.

\subsection{3.}

\section{Pré-teste do instrumento de pesquisa}

Dado se tratar de um survey auto-administrado via software de pesquisa online na internet, com o objetivo de se atingir o maior entendimento possível por parte dos participantes, foi realizado um pré-teste do questionário com dois grupos distintos de consumidores. Um grupo formado por 25 alunos de Mestrado em Administração e Pós-graduação Internacional bastante acostumados com esse tipo de questionário acadêmico, e um segundo grupo de 10 consumidores de telefonia móvel sem nenhuma experiência com resposta a questionários acadêmicos. Os respondentes foram instruídos a tomar nota de todos os problemas que encontrassem ao longo do questionário além de propor mudanças no mesmo a fim de clarificar melhor qualquer item que achassem necessário

Os resultados obtidos com esses pré-testes serviram para elaborar o instrumento final apresentado do Apêndice A.

\section{3. \\ População e amostra}

\subsection{1.}

\section{População}

De acordo com Horrigan (2003) os jovens da elite high tech são o segmento mais atrativo para investigar tecnologias inovadoras, pois sua taxa de adoção e uso de soluções tecnológicas é maior (KULVIWAT et al., 2007), além de influenciarem outros usuários menos inovadores. Rogers (2005), em sua categorização dos adotantes, quando apresenta os inovadores, acrescenta que tratam-se de pessoas mais cosmopolitas, com um certo desejo pelo diferente, arriscado e ousado, características muito comuns em jovens e jovens adultos dos dias atuais. 
O pico de utilização das redes sociais ocorre entre jovens com idade entre 16 e 24 anos (86\%). Também é alta (75\%) a utilização entre os que têm de 25 a 34 anos (MACIEL, 2013).

Em média 47\% dos usuários de mídia social fazem uso do SAC via mídia social, mesmo esse canal não sendo o oficial das empresas. Um em cada três usuários prefere o SAC através das mídias sociais, sendo que $72 \%$ desse público têm até 34 anos (NILSEN, 2012).

A população estudada foi a de jovens e jovens adultos brasileiros (menores que 34 anos) usuários de telefonia móvel e sites de mídias sociais.

\subsection{2.}

\section{Amostra}

Foi realizada uma amostragem não probabilística por conveniência já que não se tinha acesso a todos os jovens brasileiros usuários de mídias sociais que possuam serviço de telefonia móvel (CRESWELL, 2010). Foi oferecido um sorteio de um smartphone para aqueles que concluíssem o questionário, com o intuito de aumentar a participação dos respondentes e a base de dados coletada.

Apesar de se tratar de uma amostra não probabilística, teve-se o cuidado de procurar por candidatos que já façam uso de sites de mídia social e que já estejam acostumados com a utilização frequente desse tipo de sites. Um e-mail convite foi enviado para cerca de 830.000 e-mails de clientes pré-pagos de uma operadora de telefonia móvel brasileira que fazem uso de um tipo específico de plano de telefonia que não é comercializado em nenhum ponto de venda e somente assinantes que já possuam o serviço podem indicar outros usuários com integração total via mídia social. Um total de 14.697 pessoas clicou no link do convite e entraram no site onde encontraram o questionário para resposta. Deste número, 7.555 foram as pessoas que responderam o questionário até o final. Da base de dados final, foram eliminadas 2.293 respostas referentes a respondentes com idades inferiores a 15 e superiores a 34 anos e que não faziam uso de mídias sociais. Dessa forma a amostra final foi composta de 5.262 respondentes válidos. 


\section{4 . \\ Coleta de dados}

\subsection{1.}

\section{$\mathrm{O}$ instrumento de coleta de dados}

O instrumento de pesquisa foi composto de 60 itens referentes aos construtos presentes no modelo conceitual proposto e, ao final do questionário, outros 11 itens para medir variáveis demográficas e de categorização dos respondentes (CRESWELL, 2010).

Após uma breve introdução explicando o conceito de auto-atendimento através das mídias sociais e a apresentação de um curto vídeo de um serviço de uma operadora de telefonia móvel brasileira que lança mão de técnicas de endosso em mídias sociais, afim de não confundir o respondente, o questionário se inicia com os oito construtos que fazem uso da mesma escala Likert de cinco pontos ancoradas em discordo fortemente e concordo fortemente. $\mathrm{Na}$ sequência as perguntas dos três construtos restantes são feitas utilizando uma escala de diferencial semântico de cinco pontos.

\subsection{2. \\ Escolha da tecnologia a ser avaliada}

Dado que o objetivo era o de avaliar a intenção de adoção de uma nova tecnologia, é necessário que a pesquisa foque uma tecnologia que ainda não é totalmente dominada pela população e, portanto, possa ser considerada inovadora o suficiente a ponto de não estar totalmente disponível para todos (HORRIGAN, 2003 e KULVIWAT et al, 2007). Apesar de o escopo do survey aplicado se restringir a uma solução de auto-atendimento através de mídias sociais para operadoras de telefonia móvel, o objetivo é que os resultados desse estudo possam ser ampliados para qualquer escopo de adoção de soluções de auto-atendimento através de mídias sociais em qualquer indústria.

Optou-se pela utilização de uma solução de auto-atendimento onde o consumidor pudesse acessar o SAC de sua operadora de telefonia através das mídias sociais, solução essa que existe em formato de "piloto" com algumas operadoras de telefonia e não de forma totalmente automatizada. Atualmente, o consumidor entra na fan page da operadora no Facebook e envia uma mensagem 
informando o problema para que um atendente da operadora de telefonia responda-o pessoalmente.

\subsection{3.}

\section{A coleta de dados}

Os dados da pesquisa foram coletados através de ferramenta de survey online (Qualtrics) ao longo do mês de fevereiro de 2014. Jovens e jovens adultos brasileiros usuários de mídias sociais e telefonia móvel foram convidados a responder ao questionário. Entretanto, o questionário permitia que pesquisados de qualquer idade respondessem o mesmo.

Após apresentação de um vídeo introdutório, os respondentes eram direcionados a responder às perguntas do questionário auto-administrado em ambiente online.

\section{5 .}

\section{Análise dos dados}

Os dados das respostas ao questionário foram exportados da base do sistema online Qualtrics para serem "carregados" em softwares de tratamento estatístico SAS e SPSS. As análises multivariadas foram feitas utilizando os softwares SAS (versão 9), AMOS (versão 20) e SPSS (versão 20).

A análise inicial passou por um tratamento da base exportada do sistema Qualtrics a fim de garantir que a amostra estudada se enquadrasse no perfil desejado. Uma análise de possíveis erros de digitação ou valores ausentes resultou em uma base final com 5262 respondentes com dados completos e dentro do perfil desejado para o estudo: jovens e jovem adultos brasileiros com menos de 34 anos de idade e que tenham utilizado sites de mídias sociais.

\subsection{1.}

\section{Validade e Confiabilidade}

Dado que foram combinadas uma série de escalas de diversos estudos diferentes, torna-se importante restabelecer a validade e a confiabilidade do instrumento de pesquisa (CRESWELL, 2010). A confiabilidade composta está atrelada ao fato de um levantamento ser consistente ao longo do tempo. Ou seja, 
ele não deve apresentar resultados diferentes em diferentes momentos no tempo. Outra medida importante de confiabilidade é a confiabilidade interna avaliada por meio do Alpha de Cronbach que basicamente significa avaliar se um respondente adota um mesmo padrão de resposta para perguntas semelhantes.

Foi realizada uma análise fatorial confirmatória (CFA) e a análise do Alpha de Cronbach (CHURCHILL, 1979) e da confiabilidade composta (composite reliability - CR) a fim de garantir a confiabilidade. Um Alpha de Cronbach, que também é um indicador de validade convergente, superior a 0,7 já é considerado aceitável (CHURCHILL, 1979).

Mesmo que um levantamento seja confiável ele pode não fornecer uma medida válida. Validade significa saber se os itens medem de fato o construto que deveriam medir e saber se os resultados se correlacionam com outros resultados.

Para Churchill (1979) as medidas precisam ter validade convergente e discriminante. Na validade convergente é verificado se os diferentes itens que pretendem medir o mesmo construto de fato o fazem e na validade discriminante é analisado se as medidas se correlacionam muito, já que elas poderiam estar medindo a mesma coisa ao invés de construtos diferentes. A validade convergente foi medida pela variância extraída média (average variance extracted - AVE), com uma AVE maior que 0,5 sendo considerada adequada (FORNELL e LARCKER, 1981). A validade discriminante também pode ser medida por meio da AVE, bastando compará-la com o quadrado da correlação entre os construtos medidos. O valor da AVE deve ser maior do que o quadrado da correlação entre os pares de construtos para atingirmos a validade discriminante (FORNELL e LARCKER, 1981).

\subsection{2.}

\section{Análises Estatísticas}

O teste das 22 hipóteses foi feito por meio de modelagem de equações estruturais (SEM) utilizando o software AMOS (versão 20). Com a utilização de SEM é possível quantificar de que forma as variáveis observadas são indicativos indiretos de variáveis não observadas (latentes), ou construtos, além de contabilizar os erros ao longo do processo de estimativa (FORNELL e LARCKER, 1981). 


\section{6. \\ Limitações do método}

\subsection{1.}

\section{Limitações relacionadas ao critério de amostragem}

Dado não se ter acesso a todo o universo de usuários de telefonia móvel do Brasil foi adotada uma amostra não probabilística por conveniência com o envio de convites para a resposta ao questionário somente para cerca de 830.000 clientes de uma única operadora de telefonia móvel, sendo que o número total de telefones celulares no Brasil é de 271 milhões.

Entretanto, cabe ressaltar que a amostra de 7.555 respondentes foi razoavelmente significativa para que possam ser feitas inferências a cerca da população de uma maneira geral.

\subsection{2.}

\section{Limitações decorrentes da coleta de dados}

Uma limitação importante se deve ao fato de poucos usuários terem tido contato com soluções de auto-atendimento de uma maneira geral. As instruções inicias do questionário levavam os consumidores a imaginar uma solução de autoatendimento que ainda está em fase de desenvolvimento.

Especial cuidado foi tomado pelo pesquisador no sentido de utilizar uma base de clientes de telefonia móvel com acesso a um produto inovador: um serviço de telefonia móvel pré-paga que não pode ser adquirido nas lojas. A única forma de se tornar um consumidor desse serviço é sendo presenteado por algum amigo nas mídias sociais (relações de endosso nas mídias sociais). Além disso, para se tornar capaz de presentear seus amigos é necessário marcar pontos que são somados todas as vezes que se fazem posts nas mídias sociais e todas as vezes que seus posts recebem comentários e são encaminhados. 


\section{4 \\ Modelagem e análise de dados}

Neste capítulo são apresentados os resultados das avaliações demográficas, análises fatoriais, análises de confiabilidade e os testes das hipóteses de pesquisa.

\section{1.}

\section{Caracterização da amostra}

O instrumento de pesquisa (Apêndice A) foi distribuído via e-mail convite para cerca de 830.000 e-mails de clientes pré-pagos de uma operadora de telefonia móvel brasileira. Ao longo do mês de Fevereiro de 2014, 14.697 pessoas clicaram no link e entraram no site onde encontraram o questionário. Do total, 7.555 pessoas responderam o questionário até o final, sendo eliminadas 2.293 respostas (idades inferiores a 15 e superiores a 34 anos e que não faziam uso de mídias sociais). Dessa forma a amostra final foi composta de 5.262 respondentes válidos.

A tabela 4-1 abaixo mostra as características demográficas da amostra estudada. Do total de 5262 respondentes, 1820 era do sexo feminino $(34,6 \%)$ e 3442 do sexo masculino $(65,4 \%)$. A grande maioria dos respondentes se declarou solteiro $(82,7 \%), 844$ eram casados $(16,0 \%), 53$ respondentes se declararam separados/divorciados $(1,0 \%)$ e somente 5 eram viúvos $(0,1 \%)$. No que diz respeito a renda familiar, somente $3,1 \%$ declaram possuir renda superior a dez mil reais, com a maioria $74,2 \%$ apresentando renda inferior a três mil e quinhentos reais. No quesito escolaridade, a maioria, 42,2\% informaram estar cursando alguma faculdade. Em termos de idade, 50,3\% pertencem a geração $\mathrm{Z}$ nascidos entre 1990 e 2010 e 49,7\% pertencem a geração Y composta pelos nascidos entre 1980 e 1990. 
Tabela 4-1 Características da Amostra

\begin{tabular}{|c|c|c|}
\hline \multirow{2}{*}{$\begin{array}{l}\text { Característica } \\
\text { Sexo }\end{array}$} & \multicolumn{2}{|c|}{$\begin{array}{l}\text { Porcentagem de } \\
\text { respondentes e frequência } \\
\text { (n) }\end{array}$} \\
\hline & \\
\hline Feminino & $34,6 \%$ & 1820 \\
\hline Masculino & $65,4 \%$ & 3442 \\
\hline \multicolumn{3}{|l|}{ Estado Civil } \\
\hline Solteiro & $82,7 \%$ & 4351 \\
\hline Casado & $16,0 \%$ & 844 \\
\hline Separado/Divorciado & $1,0 \%$ & 53 \\
\hline Viúvo & $0,1 \%$ & 5 \\
\hline \multicolumn{3}{|l|}{ Renda Familiar } \\
\hline Abaixo de R\$ 1.000 & $20,5 \%$ & 1080 \\
\hline $\mathrm{R} \$ 1.000 \mathrm{a} \mathrm{R} \$ 2.000$ & $30,5 \%$ & 1604 \\
\hline $\mathrm{R} \$ 2.000 \mathrm{a} \mathrm{R} \$ 3.500$ & $23,2 \%$ & 1221 \\
\hline $\mathrm{R} \$ 3.500$ a $\mathrm{R} \$ 6.000$ & $16,1 \%$ & 846 \\
\hline $\mathrm{R} \$ 6.000$ a $\mathrm{R} \$ 10.000$ & $6,6 \%$ & 348 \\
\hline Acima de $\mathrm{R} \$ 10.000$ & $3,1 \%$ & 163 \\
\hline \multicolumn{3}{|l|}{ Escolaridade } \\
\hline Ensino Fundamental (1o. Grau) interrompido & $0,5 \%$ & 24 \\
\hline Ensino Fundamental (1o. Grau) cursando & $0,1 \%$ & 5 \\
\hline Ensino Fundamental (1o. Grau) completo & $0,4 \%$ & 23 \\
\hline Ensino Médio (2o. Grau) interrompido & $0,7 \%$ & 39 \\
\hline Ensino Médio (2o. Grau) cursando & $1,7 \%$ & 92 \\
\hline $\begin{array}{l}\text { Ensino Médio (2o. Grau) Profissionalizante } \\
\text { cursando }\end{array}$ & $0,9 \%$ & 45 \\
\hline Ensino Médio (2o. Grau) completo & $12,7 \%$ & 670 \\
\hline $\begin{array}{l}\text { Ensino Médio (2o. Grau) Profissionalizante } \\
\text { completo }\end{array}$ & $3,7 \%$ & 194 \\
\hline Formação Superior interrompida & $5,9 \%$ & 312 \\
\hline Formação Superior cursando & $42,2 \%$ & 2222 \\
\hline Formação Superior completa & $19,4 \%$ & 1023 \\
\hline Pós-graduação no nível Especialização & $8,4 \%$ & 442 \\
\hline Pós-graduação no nível Mestrado & $2,7 \%$ & 143 \\
\hline Pós-graduação no nível Doutorado & $0,5 \%$ & 28 \\
\hline \multicolumn{3}{|l|}{ Idade } \\
\hline $15-24$ & $50,3 \%$ & 2647 \\
\hline $25-34$ & $49,7 \%$ & 2615 \\
\hline Média & \multicolumn{2}{|c|}{24,86} \\
\hline Desvio Padrão & \multicolumn{2}{|c|}{4,339} \\
\hline Mínimo & \multicolumn{2}{|c|}{15} \\
\hline Máximo & \multicolumn{2}{|c|}{34} \\
\hline
\end{tabular}




\section{2.}

\section{Análises e Resultados}

\subsection{1.}

\section{Avaliação do modelo de mensuração}

O modelo inicialmente testado com todos os 60 indicadores medidos no instrumento de pesquisa apresentou bons índices de avaliação, com um RMSEA (mean-squared error of approximation) de 0,051 (com intervalo de confiança de 0,051 até 0,052), um CFI (comparative fit index) de 0,850, um IFI (incremental fit index) de 0,850, um TLI (Tucker-Lewis index) de 0,839 e um valor significativo para índice qui-quadrado $\left(\chi^{2}=24701,70\right.$, d.f. $=1655, \mathrm{p}<0,001, \chi^{2} /$ d.f. $\left.=14,93\right)$ além de um SRMR (standardized root mean square) de 0,0623. De acordo com Hair et al. (2009) o modelo apresenta um fit razoável mas ainda existia espaço para melhorá-lo.

Após a análise fatorial confirmatória (CFA) do modelo, foram observados diversos itens que contribuíam para o fit não muito bom do modelo. Após uma série de modificações e testes de refinamento, foram excluídos 18 itens, o que resultou em um modelo final de 42 itens. Os itens excluídos foram: o item 1 da escala de Força de Ligação com os Pares, os itens 4 e 5 da escala de Afeto, o item 4 da escala de Facilidade de Uso Percebida, o item 2 da escala de Envolvimento com o Produto e os itens $1,2,3,4,6,7,8,9,10,11,14,15$ e 16 da escala de Narcisismo Social.

O modelo de mensuração refinado, com 42 itens, apresentou uma sensível melhora nos índices de avaliação do fit, com um RMSEA de 0,041 (com intervalo de confiança de 0,041 até 0,042), um CFI de 0,947, um IFI de 0,947, um TLI de 0,940, um $\chi^{2}=7650,21$ com d.f. $=764, \mathrm{p}<0,001$ e $\chi^{2} /$ d.f. $=10,01$ e, por fim, um $\mathrm{SRMR}=0,0445$, resultados que indicam um melhor ajuste para o modelo proposto. 


\subsection{2.}

\section{Validade e Confiabilidade}

Após utilizar a CFA para refinar o modelo de mensuração e melhorar seu fit, é necessário verificar a validade das medidas realizadas, a fim de garantir a assertividade da pesquisa. Busca-se verificar se os itens medem de fato os construtos que deveriam medir e saber se os resultados se correlacionam com outros resultados. De acordo com Hair et al. (2009) devemos considerar quatro componentes de validades dos construtos: validade convergente, discriminante, nomológica e de face.

A validade de face deve ser garantida antes dos testes propriamente ditos e tem a ver com a questão de garantir que as perguntas que estão sendo feitos sejam compreendidas pelos entrevistados. Como explicado no Capítulo 3, as fases de tradução é pré-teste buscavam exatamente garantir que o instrumento de pesquisa ficasse o mais claro e simples possível para o entrevistado, sem perder a apreciação do que de fato se queria medir.

$\mathrm{Na}$ validade nomológica busca-se verifica se as correlações entre os construtos fazem sentido garantindo que a teoria pesquisada, que apontava para tais relações, de fato estava correta. O quadro 4-1 apresenta a matriz de correlação entre construtos no intuito de facilitar essa análise.

\section{Quadro 4-1 Matriz de Correlação entre Construtos}

임

\begin{tabular}{|c|c|c|c|c|c|c|c|c|c|c|c|}
\cline { 2 - 12 } & TSP & IPG & COM & AFE & ANS & UP & FUP & IU & EP & ATT & NS \\
\hline IPG & $\mathbf{1}$ & 0,61 & 0,44 & 0,135 & $0,01 *$ & 0,214 & 0,245 & 0,257 & 0,193 & 0,162 & $0,035^{*}$ \\
\hline COM & 0,44 & $\mathbf{1}$ & 0,608 & 0,296 & 0,134 & 0,27 & 0,281 & 0,277 & 0,197 & 0,173 & $-0,063$ \\
\hline AFE & 0,135 & 0,296 & 0,276 & $\mathbf{1}$ & 0,133 & 0,623 & 0,496 & 0,491 & 0,454 & 0,507 & $-0,168$ \\
\hline ANS & $0,01 *$ & 0,134 & 0,136 & 0,133 & $\mathbf{1}$ & $-0,142$ & $-0,246$ & $-0,195$ & $-0,237$ & $-0,247$ & $-0,081$ \\
\hline UP & 0,214 & 0,27 & 0,245 & 0,623 & $-0,142$ & $\mathbf{1}$ & 0,743 & 0,737 & 0,648 & 0,654 & $-0,061$ \\
\hline FUP & 0,245 & 0,281 & 0,254 & 0,496 & $-0,246$ & 0,743 & $\mathbf{1}$ & 0,675 & 0,574 & 0,599 & $-0,091$ \\
\hline IU & 0,257 & 0,277 & 0,256 & 0,491 & $-0,195$ & 0,737 & 0,675 & $\mathbf{1}$ & 0,719 & 0,689 & $0,012^{*}$ \\
\hline EP & 0,193 & 0,197 & 0,185 & 0,454 & $-0,237$ & 0,648 & 0,574 & 0,719 & $\mathbf{1}$ & 0,853 & $-0,008^{*}$ \\
\hline ATT & 0,162 & 0,173 & 0,154 & 0,507 & $-0,247$ & 0,654 & 0,599 & 0,689 & 0,853 & $\mathbf{1}$ & $-0,022^{*}$ \\
\hline NS & $0,035^{*}$ & $-0,063$ & $-0,052$ & $-0,168$ & $-0,081$ & $-0,061$ & $-0,091$ & $0,012 *$ & $-0,008^{*}$ & $-0,022^{*}$ & $\mathbf{1}$ \\
\hline
\end{tabular}

* = correlação não significativa 
Onde:

- $\quad$ TSP = Força de Ligação com os Pares

- $\quad \mathrm{IPG}=$ Identificação com o grupo de pares

- $\mathrm{COM}=$ Comunicação com os pares

- $\mathrm{AFE}=$ Afeto

- $\quad$ ANS $=$ Ansiedade

- $\quad \mathrm{UP}=$ Utilidade Percebida

- $\quad$ FUP $=$ Facilidade de Uso Percebida

- $\quad \mathrm{IU}=$ Intenção de Uso

- $\mathrm{EP}=$ Envolvimento com o produto

- $\quad \mathrm{ATT}=$ Atitude

- $\mathrm{NS}=$ Narcisismo Social

Quase todas as correlações expostas no quadro 4-1 foram significativas a um nível de significância de 0,001, com as relações Narcisismo Social / Comunicação com os Pares e Narcisismo Social / Identificação com os Pares significativas a 0,01 . As relações que não foram significativas são: Narcisismo Social / Intenção de Uso, Narcisismo Social / Envolvimento com o Produto e Narcisismo Social / Atitude além de apresentarem fatores muito próximos de zero indicando que não existe nenhuma correlação entre tais construtos. As correlações negativas que aparecem em relação a Ansiedade são normais dado se tratar de um construto inverso com relação ao restante do modelo. Por exemplo, uma vez que o respondente julgue que uma determinada tecnologia traz vantagens (utilidade percebida) e que ela seja de fácil utilização (facilidade de uso percebida) é natural que eu fique menos ansioso em utilizar aquela solução dado que eu entendo do que se trata. Para além da dimensão cognitiva o mesmo raciocínio se aplica, se um consumidor tem intenção de utilizar um produto (intenção de uso), já desenvolveu um certo envolvimento com o mesmo (envolvimento com o produto) e possui uma atitude positiva com relação a esse produto (atitude com relação ao produto), também é natural que ele se sinta menos ansioso com relação ao mesmo já que a excitação de uma eventual novidade não existe mais. Portanto podemos concluir que existe validade nomológica. 
A tabela 4-2 a seguir, apresenta os coeficientes Alpha de Cronbach calculados para as escalas presentes no modelo de mensuração final (composto de 42 itens) e as confiabilidades compostas dos construtos. Coeficientes de confiabilidade composta e Alfa de Cronbach entre 0,7 e 0,8 são considerados aceitáveis e maiores que 0,8 são considerados bons (HAIR et al., 2009). Como pode ser observado, todos os coeficientes apresentam valores superiores a $0,7 \mathrm{com}$ exceção do construto Narcisismo Social, que apresentou um valor de 0,54.

Para verificação da validade convergente foi utilizado o AVE (average variance extracted). Nesse teste devemos ter índices superiores a 0,5 para uma validade convergente adequada (FORNELL e LARCKER, 1981). Os resultados também estão apresentados na tabela 4-2. Dois valores de AVE calculados estão abaixo de 0,5 indicando que a variância devida a erro na medida é maior do que a variância do construto como um todo. Apesar disso, como a AVE é uma medida mais conservadora do que a confiabilidade do construto, apontando para uma variância de $66 \%$ baseada em erro, ainda é possível se concluir em favor da verificação da validade convergente para o modelo apresentado (FORNELL e LARCKER, 1981, p. 46) com uma confiabilidade composta mais próxima do limite de 0,7 proposto pela literatura. De qualquer forma são fortes os indícios de que o construto Narcisismo Social apresenta problemas de medição e qualquer conclusão baseada no mesmo precisaria ser confirmada por meio de outros estudos.

Tabela 4-2 Confiabilidade, Confiabilidade Composta e AVE

\begin{tabular}{l|c|c|c}
\hline \multicolumn{2}{l}{$\begin{array}{c}\text { Confiabilidade } \\
(\boldsymbol{\alpha})\end{array}$} & $\begin{array}{c}\text { Confiabilidade } \\
\text { Composta }\end{array}$ & $\begin{array}{c}\text { Variância } \\
\text { Extraída } \\
\text { Media } \\
\text { (AVE) }\end{array}$ \\
\hline Força de Ligação Entre os Pares & 0,74 & 0,76 & 0,53 \\
\hline $\begin{array}{l}\text { Identificação com o Grupo de } \\
\text { Pares }\end{array}$ & 0,81 & 0,70 & 0,47 \\
\hline Comunicação com os Pares & 0,90 & 0,91 & 0,66 \\
\hline Afeto & 0,78 & 0,79 & 0,57 \\
\hline Ansiedade & 0,82 & 0,82 & 0,54 \\
\hline Utilidade Percebida & 0,92 & 0,92 & 0,71 \\
\hline Facilidade de Uso Percebida & 0,89 & 0,89 & 0,63 \\
\hline Intenção de Uso & 0,89 & 0,89 & 0,74 \\
\hline Envolvimento com o Produto & 0,82 & 0,66 & 0,60 \\
\hline
\end{tabular}




\begin{tabular}{l|c|c|c}
\hline Escala & \multicolumn{1}{c}{$\begin{array}{c}\text { Confiabilidade } \\
(\boldsymbol{\alpha})\end{array}$} & $\begin{array}{c}\text { Confiabilidade } \\
\text { Composta }\end{array}$ & $\begin{array}{c}\text { Variância } \\
\text { Extraída } \\
\text { Media } \\
(\text { AVE) }\end{array}$ \\
\hline Atitude & 0,92 & 0,92 & 0,79 \\
\hline Narcisismo Social & 0,54 & 0,61 & 0,34 \\
\hline
\end{tabular}

Também foram avaliadas as cargas fatoriais de cada item de cada construto com suas respectivas significâncias. Quanto maiores forem esses fatores, maiores as chances de que os itens medem os construtos que pretendiam medir. Valores acima de 0,7 são esperados, com significância e no sentido em que a literatura apontava. A tabela 4-3 apresenta os resultados.

Tabela 4-3 Cargas Fatoriais Padronizadas

\begin{tabular}{lcc}
\hline Construto/Indicador & $\begin{array}{c}\text { Carga Fatorial } \\
\text { Padronizada }\end{array}$ & p-valor \\
\hline Força de Ligação Entre os Pares & & \\
\hline TSP2 & 0,57 & $<0,001$ \\
TSP3 & 0,80 & $<0,001$ \\
TSP4 & 0,78 & $<0,001$ \\
\hline Identificação com o Grupo de & & \\
Pares & 0,70 & $<0,001$ \\
\hline IPG1 & 0,64 & $<0,001$ \\
IPG2 & 0,65 & $<0,001$ \\
IPG3 & 0,67 & $<0,001$ \\
IPG4 & 0,74 & $<0,001$ \\
IPG5 & & $<0,001$ \\
\hline Comunicação com os Pares & $<0,001$ \\
\hline COM1 & 0,75 & $<0,001$ \\
COM2 & 0,81 & $<0,001$ \\
COM3 & 0,85 & $<0,001$ \\
COM4 & 0,86 & \\
COM5 & 0,77 & $<0,001$ \\
\hline Afeto & & $<0,001$ \\
\hline AFE1 & & $<0,001$ \\
AFE2 & 0,64 & $<0,001$ \\
AFE3 & 0,78 & \\
\hline Narcisismo Social & 0,001 \\
\hline NS5 & 0,53 & \\
NS12 & & \\
NS13 & 0,54 & \\
\hline Atitude & & \\
\hline & 0,59 & \\
\hline & & \\
\hline
\end{tabular}




\begin{tabular}{lcc}
\hline Construto/Indicador & $\begin{array}{c}\text { Carga Fatorial } \\
\text { Padronizada }\end{array}$ & p-valor \\
\hline ATT1 & 0,90 & $<0,001$ \\
ATT2 & 0,89 & $<0,001$ \\
ATT3 & 0,89 & $<0,001$ \\
\hline Intenção de Uso & & \\
\hline IU1 & 0,80 & $<0,001$ \\
IU2 & 0,90 & $<0,001$ \\
IU3 & 0,87 & $<0,001$ \\
\hline Envolvimento com o Produto & & \\
\hline EP1 & 0,79 & $<0,001$ \\
EP3 & 0,83 & $<0,001$ \\
EP4 & 0,70 & $<0,001$ \\
\hline Facilidade de Uso Percebida & & $<0,001$ \\
\hline FUP1 & 0,74 & $<0,001$ \\
FUP2 & 0,79 & $<0,001$ \\
FUP3 & 0,85 & $<0,001$ \\
FUP5 & 0,74 & $<0,001$ \\
FUP6 & 0,82 & $<0,001$ \\
\hline Utilidade Percebida & & $<0,001$ \\
\hline UP1 & 0,82 & $<0,001$ \\
UP2 & 0,86 & $<0,001$ \\
UP3 & 0,89 & $<0,001$ \\
UP4 & 0,83 & $<0,001$ \\
UP5 & 0,80 & $<0,001$ \\
\hline Ansiedade & 0,69 & \\
\hline ANS1 & 0,71 & 0,82 \\
ANS2 & 0,71 & \\
ANS3 & & \\
ANS4 & & \\
\hline & & \\
\hline
\end{tabular}

Como é possível observar, todos os itens apresentaram cargas fatoriais relativamente altas e significativas, além de também possuírem a direção esperada. Apesar de algumas cargas apresentarem valores inferiores a 0,6 (valor tido como limite mínimo pela literatura para se concluir validade convergente), como as cargas foram significativas e com boa magnitude, julga-se que foram verificadas a unidimensionalidade e a validade convergente dos construtos.

Para a avaliação de validade discriminante, Fornell e Larcker (1981) sugerem a comparação da variância extraída média (AVE) de cada construto com a variância compartilhada entre todos os pares de construtos. A validade discriminante é verificada quando todos os construtos apresentam variâncias extraídas maiores do que as respectivas variâncias compartilhadas, indicando que 
os itens se relacionam mais fortemente com os construtos que se propõem a medir do que com outros construtos do modelo. As variâncias compartilhadas nada mais são do que o quadrado de cada item da matriz de correlação entre construtos (Quadro 4-1). No quadro 4-2 é apresentado a Matriz de Validade Discriminante, com a AVE ao longo da sua diagonal.

\section{Quadro 4-2 Matriz de Validade Discriminante}

\begin{tabular}{|c|c|c|c|c|c|c|c|c|c|c|c|}
\hline & TSP & IPG & COM & AFE & ANS & UP & FUP & IU & EP & ATT & NS \\
\hline TSP & $\mathbf{0 , 5 3}$ & 0,37 & 0,19 & 0,02 & 0,00 & 0,05 & 0,06 & 0,07 & 0,04 & 0,03 & 0,00 \\
\hline IPG & 0,37 & 0,47 & 0,37 & 0,09 & 0,02 & 0,07 & 0,08 & 0,08 & 0,04 & 0,03 & 0,00 \\
\hline COM & 0,19 & 0,37 & 0,66 & 0,08 & 0,02 & 0,06 & 0,06 & 0,07 & 0,03 & 0,02 & 0,00 \\
\hline AFE & 0,02 & 0,09 & 0,08 & $\mathbf{0 , 5 7}$ & 0,02 & 0,39 & 0,25 & 0,24 & 0,21 & 0,26 & 0,03 \\
\hline ANS & 0,00 & 0,02 & 0,02 & 0,02 & 0,54 & 0,02 & 0,06 & 0,04 & 0,06 & 0,06 & 0,01 \\
\hline UP & 0,05 & 0,07 & 0,06 & 0,39 & 0,02 & 0,71 & 0,55 & 0,54 & 0,42 & 0,43 & 0,00 \\
\hline rUP & 0,06 & 0,08 & 0,06 & 0,25 & 0,06 & 0,55 & 0,63 & 0,46 & 0,33 & 0,36 & 0,01 \\
\hline IU & 0,07 & 0,08 & 0,07 & 0,24 & 0,04 & 0,54 & 0,46 & 0,74 & 0,52 & 0,47 & 0,00 \\
\hline EP & 0,04 & 0,04 & 0,03 & 0,21 & 0,06 & 0,42 & 0,33 & 0,52 & 0,60 & 0,73 & 0,00 \\
\hline TT & 0,03 & 0,03 & 0,02 & 0,26 & 0,06 & 0,43 & 0,36 & 0,47 & 0,73 & 0,79 & 0,00 \\
\hline NS & 0,00 & 0,00 & 0,00 & 0,03 & 0,01 & 0,00 & 0,01 & 0,00 & 0,00 & 0,00 & 0,34 \\
\hline
\end{tabular}

Salvo no caso da correlação entre Atitude / Envolvimento com o Produto, todas as variâncias compartilhadas foram inferiores ao respectivo AVE. Essa falha pode ter sido causada pelo fato dos itens de cada um dos dois construtos em questão estarem medindo uma parcela do segundo construto.

Por fim, com uma pequena ressalva com relação ao construto Narcisismo Social, é possível afirmar que o modelo de mensuração proposto atende aos requisitos desejados para confiabilidade, unidimensionalidade, validade de face, nomológica, convergente e discriminante permitindo que um modelo de equações estruturais possa ser utilizado para investigar as relações entre os construtos latentes.

\subsection{3.}

\section{Análise do Modelo Estrutural}

Para testar o modelo proposto e as hipóteses de pesquisa foi utilizada a técnica de equações estruturais (SEM) utilizando o software AMOS (versão 20). 
Inicialmente será feita a modelagem da estrutura proposta e a verificação de seu fit apresentado os índices adequados para tal avaliação. $\mathrm{O}$ modelo aqui testado já é baseado no modelo de mensuração refinado composto por 42 indicadores.

\subsubsection{1.}

\section{Ajuste do Modelo Proposto}

$\mathrm{Na}$ figura 4-1 é apresentado o modelo proposto com suas hipóteses. O modelo obteve um valor significativo para índice qui-quadrado $\left(\chi^{2}=12295,88\right.$, d.f. $=802, \mathrm{p}<0,001, \chi^{2} /$ d.f. $\left.=15,33\right)$. Como pode ser observado, a razão $\chi^{2} /$ d.f. foi muito alta, e o principal motivo é o fato de se tratar de uma medida sensível ao tamanho da amostra e a violações de premissa de normalidade (BENTLER e BONETT, 1980; HAIR et al., 2009).

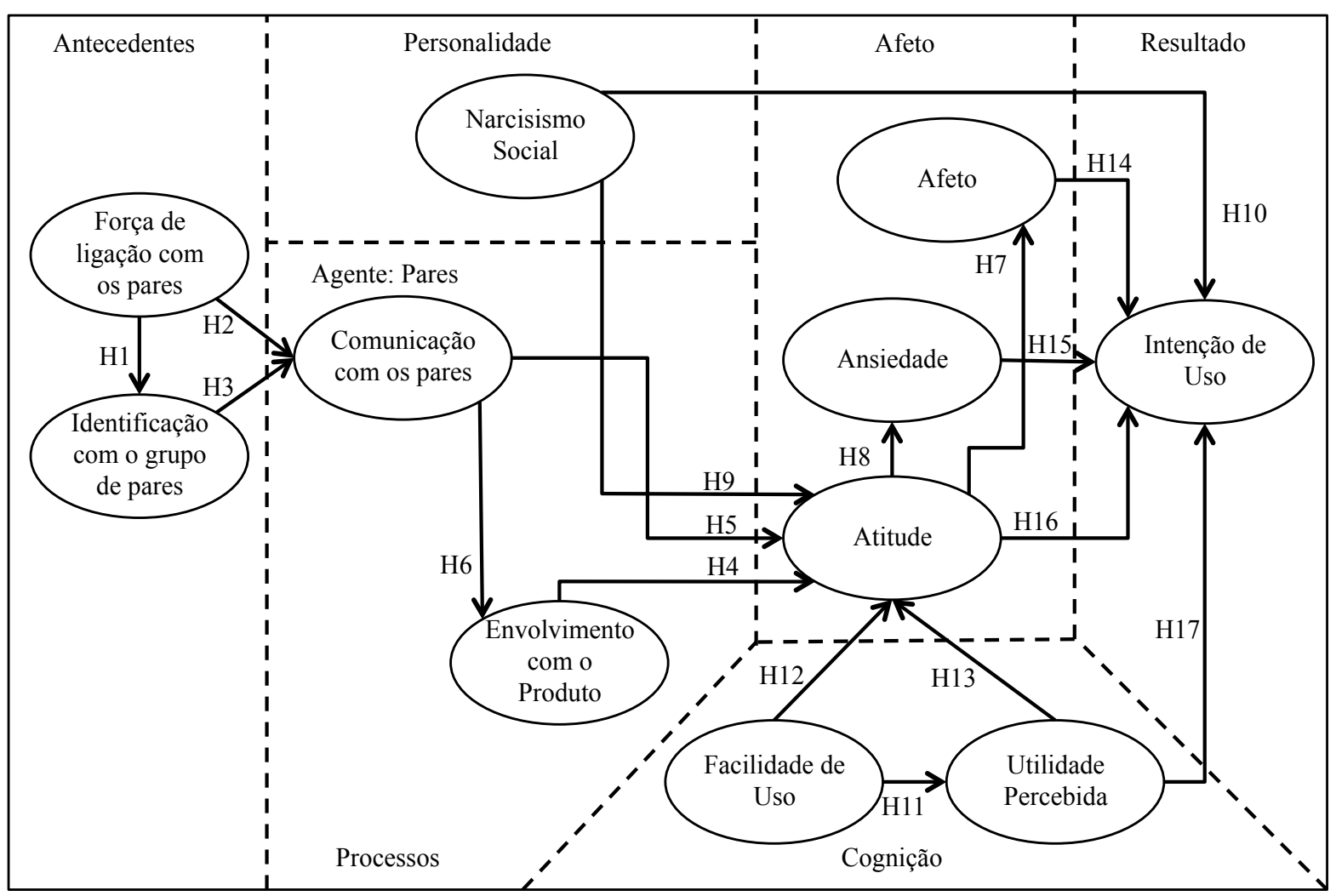

Figura 4-1 Modelo Conceitual Proposto com Hipóteses

Todos os outros índices apresentaram um bom ajuste do modelo aos dados. Os índices de ajuste incremental foram superiores a 0,90, com um CFI (comparative fit index) de 0,912, um IFI (incremental fit index) de 0, 912, um TLI 
(Tucker-Lewis index) de 0,905. O índice de ajuste absoluto RMSEA (meansquared error of approximation) foi de 0,052 (com intervalo de confiança de 0,051 até 0,053). A tabela 4-4 apresenta o resumo dos dados aqui discutidos e uma comparação com o proposto na literatura. Apesar de o SRMR calculado ter sido maior do que o limite proposto por parte da literatura (HAIR et al., 2009; BENTLER e BONETT, 1980), existem evidências que apontam para um valor mínimo aceitável superior a 0,1 para o índice SRMR devido ao tamanho da amostra ser maior do que 5000 respondentes (SIVO et al., 2006). Portanto, é possível concluir que o ajuste do modelo é satisfatório.

Tabela 4-4 Índices de Ajuste do Modelo Proposto

\begin{tabular}{lcc}
\hline Índice de Ajuste & $\begin{array}{c}\text { Modelo } \\
\text { Proposto }\end{array}$ & $\begin{array}{c}\text { Valor sugerido } \\
\text { pela literatura }\end{array}$ \\
\hline$\chi^{2} /$ d.f. & 15,33 & $\leq 3$ \\
CFI & 0,912 & $\geq 0,90$ \\
TLI & 0,905 & $\geq 0,90$ \\
IFI & 0,912 & $\geq 0,90$ \\
RMSEA & 0,052 & $\leq 0,07$ \\
SRMR & 0,137 & $\leq 0,1$ \\
\hline
\end{tabular}

\subsubsection{2.}

\section{Teste das Hipóteses de Pesquisa}

Após a verificação dos índices de ajuste dos modelos de mensuração e do modelo estrutural, foram avaliados os coeficientes estimados para as relações causais. Foi verificada a direção, magnitude e significância dos coeficientes padronizados estimados. Os coeficientes estimados, significância e as hipóteses são apresentados da tabela 4-5 e na figura 4-2. Quinze relações foram consideradas significativas com nível de significância de 0,001 e uma foi considerada significativa com nível de significância de 0,05. Somente duas relações não apresentaram significância. 
Tabela 4-5 Coeficientes Padronizados Estimados, Hipóteses e Significâncias para o Modelo Estrutural Proposto

\begin{tabular}{|c|c|c|c|}
\hline Relação Proposta & $\begin{array}{c}\text { Coeficiente } \\
\text { Padronizado }\end{array}$ & p-valor & $\begin{array}{c}\text { Hipótese } \\
\text { Verificada }\end{array}$ \\
\hline $\mathrm{H}_{1}: \mathrm{TSP} \rightarrow \mathrm{IPG}$ & 0,61 & $<0,001$ & $\operatorname{sim}$ \\
\hline $\mathrm{H}_{2}: \mathrm{TSP} \rightarrow \mathrm{COM}$ & 0,11 & $<0,001$ & $\operatorname{sim}$ \\
\hline $\mathrm{H}_{3}: \mathrm{IPG} \rightarrow \mathrm{COM}$ & 0,55 & $<0,001$ & $\operatorname{sim}$ \\
\hline $\mathrm{H}_{4}: \mathbf{E P} \rightarrow \mathrm{ATT}$ & 0,75 & $<0,001$ & $\operatorname{sim}$ \\
\hline $\mathrm{H}_{5}: \mathrm{COM} \rightarrow \mathrm{ATT}$ & $-0,05$ & $<0,001$ & não \\
\hline $\mathrm{H}_{6}: \mathrm{COM} \rightarrow \mathrm{EP}$ & 0,19 & $<0,001$ & $\operatorname{sim}$ \\
\hline $\mathbf{H}_{7}: \mathbf{A T T} \rightarrow \mathbf{A F E}$ & 0,47 & $<0,001$ & $\operatorname{sim}$ \\
\hline $\mathrm{H}_{8}: \mathbf{A T T} \rightarrow$ ANS & $-0,22$ & $<0,001$ & $\operatorname{sim}$ \\
\hline $\mathrm{H}_{9}: \mathrm{NS} \rightarrow \mathrm{ATT}$ & $-0,01$ & 0,76 & não \\
\hline $\mathrm{H}_{10}: \mathrm{NS} \rightarrow \mathrm{IU}$ & 0,06 & $<0,001$ & $\operatorname{sim}$ \\
\hline $\mathbf{H}_{11}: \mathbf{F U P} \rightarrow \mathbf{U P}$ & 0,75 & $<0,001$ & $\operatorname{sim}$ \\
\hline $\mathrm{H}_{12}: \mathrm{FUP} \rightarrow \mathrm{ATT}$ & 0,17 & $<0,001$ & $\operatorname{sim}$ \\
\hline $\mathbf{H}_{13}: \mathbf{U P} \rightarrow \mathbf{A T T}$ & 0,24 & $<0,001$ & $\operatorname{sim}$ \\
\hline $\mathrm{H}_{14}: \mathrm{AFE} \rightarrow \mathrm{IU}$ & 0,01 & 0,18 & não \\
\hline $\mathrm{H}_{15}: \mathrm{ANS} \rightarrow \mathrm{IU}$ & $-0,03$ & $<0,05$ & $\operatorname{sim}$ \\
\hline $\mathrm{H}_{16}: \mathrm{ATT} \rightarrow \mathrm{IU}$ & 0,38 & $<0,001$ & $\operatorname{sim}$ \\
\hline $\mathrm{H}_{17}: \mathrm{UP} \rightarrow \mathrm{IU}$ & 0,51 & $<0,001$ & $\operatorname{sim}$ \\
\hline
\end{tabular}

Onde:

- $\quad$ TSP = Força de Ligação com os Pares

- $\quad$ IPG = Identificação com o grupo de pares

- $\mathrm{COM}=$ Comunicação com os pares

- $\mathrm{AFE}=$ Afeto

- $\quad$ ANS $=$ Ansiedade

- $\quad \mathrm{UP}=$ Utilidade Percebida

- $\quad$ FUP $=$ Facilidade de Uso Percebida

- $\quad \mathrm{IU}=$ Intenção de Uso

- $\quad \mathrm{EP}=$ Envolvimento com o produto

- $\mathrm{ATT}=$ Atitude

- $\quad \mathrm{NS}=$ Narcisismo Social 
Como pode ser observado na tabela 4-5 e na figura 4-2 a seguir, foi obtido suporte para 14 das 17 hipóteses propostas, com relações significativas em todas as 14 (sendo 13 com significância a um nível de 0,001 e uma a um nível de 0,05).

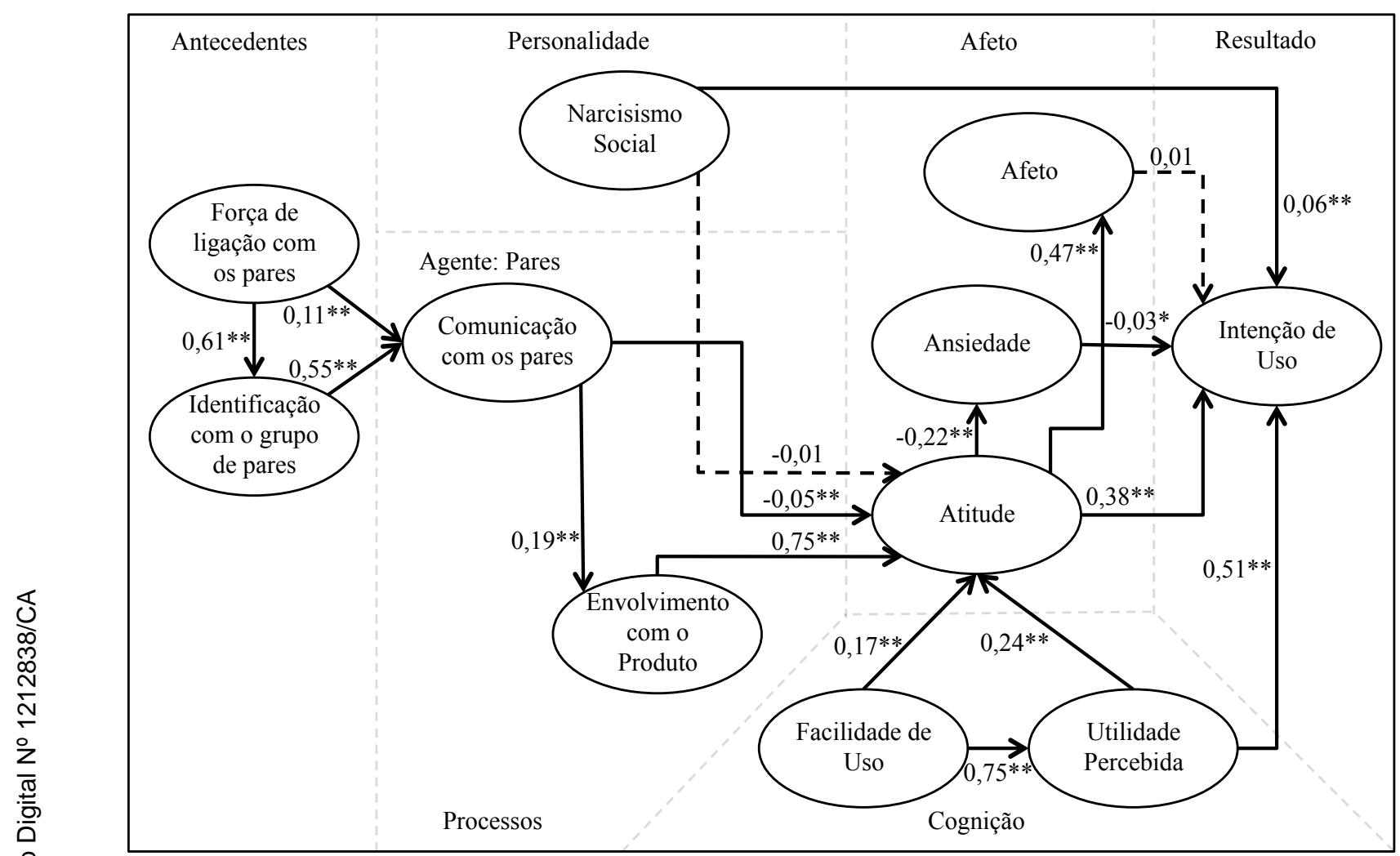

\section{Figura 4-2 Coeficientes Padronizados Estimados para o Modelo Proposto $(* *$ indica p-valor $<0,001 ; *$ indica p-valor $<0,05)$}

$\mathrm{Na}$ análise dos antecedentes, as hipóteses $\mathrm{H} 1$ até $\mathrm{H} 3$ tratam das relações de endosso nas mídias sociais sobre o processo de comunicação utilizando os pares como agentes de comunicação. Todas essas relações foram consideradas significativas com nível de significância de 0,001, confirmando as hipóteses de pesquisa inicialmente postuladas. A força de ligação com os pares e a identificação com o grupo de pares teve efeito positivo sobre comunicação com os pares (H2 e H3). A força de ligação com os pares também se relacionou positivamente com a identificação com o grupo de pares (H1) em linha com as relações encontradas por Wang et al. (2012).

Com relação ao efeito direto do impacto normativo (conformidade com os pares) e ao efeito indireto do impacto informacional via envolvimento com o produto 
sobre as atitude, as hipóteses de H4 e H5 apresentaram significância ao nível de 0,001. Entretanto, o efeito da relação da comunicação com os pares sobre a atitude apresentou um efeito direto e negativo porém relativamente fraco (coeficiente de 0,05) que contrariam os resultados encontrados por Wang et al. (2012) onde aparecem resultados positivos para essa relação. Apesar de o impacto normativo não ter sido confirmado diretamente sobre a atitude, um efeito indireto da conformidade com os pares via envolvimento com o produto (H6 com coeficiente $0,19)$ foi significativo $(<0,001)$, com coeficiente estimado de 0,14. Portanto, existem influências das relações de endosso via mídias sociais nas dimensões afetivas na intenção de adoção de uma nova tecnologia.

Os construtos de afeto e ansiedade são, na verdade, as componentes positivas e negativas da dimensão afetiva. No modelo proposto é confirmada a relação entre atitude e afeto $(\mathrm{H} 7)$ em direção, significância $(<0,001)$ e magnitude (coeficiente padronizado de 0,47$)$. Como as relações que tem como causa a ansiedade são invertidas, todas as relações de causa e efeito são invertidas, e nesse caso está confirmado que existe uma relação entre atitude e ansiedade com efeito direto e negativo confirmando a hipótese $\mathrm{H} 8$ (coeficiente padronizado de -0,22 e p-valor $<0,001)$.

Uma das grandes contribuições dessa pesquisa é a adição de um construto que avalie fatores psicológicos dos entrevistados e avalie de que forma essas relações se estabelecem dentro de um modelo de intenção de uso de uma nova tecnologia. Avaliando a interação do narcisismo social sobre atitude (H9), é observado que não existe efeito significativo $(\mathrm{p}$-valor $=0,76)$ e que, portanto, tal relação não deve existir. Entretanto, a relação direta entre narcisismo social e a intenção de uso (H10) foi significativa ao nível de 0,001, apesar de apresentar coeficiente padronizado com baixa magnitude $(0,06)$. Portanto, existem indícios que apontam para uma relação direta entre o fato de um consumidor ser narcisista e sua intenção de adotar ou não uma nova tecnologia.

As hipóteses H11 a H13, são oriundas do Modelo TAM (Davis et al., 1989) e representam a avaliação cognitiva da tecnologia afetando a atitude. Todas essas as relações foram confirmadas em direção, significância e com boa magnitude.

Por fim, as hipóteses H14 a H17 investigam a relação entre as dimensões afetivas e cognitivas sobre a intenção de uso. A hipótese H14 não foi confirmada, pois não houve significância na relação entre afeto e intenção de uso (p-valor = 
0,18). Para todas as outras relações, a direção e significância foram alcançadas com nível de 0,05 para H15 e nível de 0,001 para H16 e H17. Quanto à magnitude, os coeficientes padronizado mostram que a maior parte da intenção de uso é explicada pelas dimensões afetivas e cognitivas, com uma pequena contribuição da questão da personalidade narcísica.

\section{3. \\ Discussão dos Resultados}

Neste item serão discutidos os resultados da pesquisa e implicações. Ficaram claras as relações das dimensões cognitivas e afetivas sobre a intenção de uso. Como já apresentado anteriormente, 14 hipóteses de pesquisa foram verificadas do total de 17. A tabela 4-6 apresenta um resumo dos resultados encontrados.

Tabela 4-6 Resumo dos Resultados dos Testes de Hipóteses

\begin{tabular}{lc} 
Hipótese de Pesquisa & $\begin{array}{c}\text { Hipótese } \\
\text { Verificada }\end{array}$ \\
\hline
\end{tabular}

$\mathbf{H}_{\mathbf{1}}$ : A força de ligação com os pares tem um efeito direto e positivo com a identificação com o grupo de pares.

$\operatorname{sim}$

$\mathbf{H}_{2}$ : A força de ligação com os pares tem um efeito direto e positivo na comunicação entre os pares.

$\operatorname{sim}$

$\mathbf{H}_{3}$ : A identificação com o grupo de pares tem um efeito direto e positivo associado com a comunicação com os pares.

$\operatorname{sim}$

$\mathbf{H}_{4}$ : O envolvimento com o produto afeta direta e positivamente a atitude com relação ao produto ou serviço.

$\operatorname{sim}$

$\mathbf{H}_{\mathbf{5}}$ : A comunicação entre os pares afeta direta e positivamente a atitude com relação ao produto ou serviço.

não

$\mathbf{H}_{6}$ : A comunicação entre os pares afeta direta e positivamente o envolvimento com o produto ou serviço.

$\operatorname{sim}$

$\mathbf{H}_{7}$ : A atitude com relação ao produto afeta direta e positivamente o afeto.

$\operatorname{sim}$

$\mathbf{H}_{\mathbf{8}}$ : A atitude com relação ao produto afeta direta e negativamente a ansiedade.

$\operatorname{sim}$

$\mathbf{H}_{\mathbf{9}}$ : O narcisismo social afeta direta e positivamente a atitude. não

$\mathbf{H}_{\mathbf{1 0}}$ : O narcisismo social afeta direta e positivamente a intenção de uso.

$\operatorname{sim}$ 
$\mathbf{H}_{\mathbf{1 1}}$ : Facilidade de uso tem um efeito direto e positivo sobre utilidade percebida.

$\operatorname{sim}$

$\mathbf{H}_{\mathbf{1 2}}$ : Facilidade de uso tem um efeito direto e positivo sobre atitude com relação ao produto.

$\operatorname{sim}$

$\mathbf{H}_{13}$ : Utilidade percebida tem um efeito direto e positivo sobre atitude com relação ao produto.

$\operatorname{sim}$

$\mathbf{H}_{\mathbf{1 4}}$ : O afeto tem um efeito direto e positivo sobre a intensão de uso.

não

$\mathbf{H}_{\mathbf{1 5}}$ : A ansiedade tem um efeito direto e negativo sobre a intensão de uso.

$\operatorname{sim}$

$\mathbf{H}_{16}$ : A atitude com relação ao produto tem um efeito direto e positivo sobre a intensão de uso.

$\operatorname{sim}$

$\mathbf{H}_{17}$ : Utilidade percebida tem um efeito direto e positivo sobre a intensão de uso.

$\operatorname{sim}$

\subsection{1.}

\section{Influência das relações de endosso em mídias sociais}

$\mathrm{Na}$ análise dos antecedentes que tratam das relações de endosso nas mídias sociais sobre o processo de comunicação foi possível observar que existem influências significativas entre os três construtos. Tanto a direção quanto a significância das relações foram confirmadas, mas é interessante notar que o efeito indireto da força de ligação com os pares sobre a comunicação com os pares mediado pela identificação com o grupo de pares é maior do que o efeito direto da força de ligação sobre a comunicação com coeficientes de 0,34 contra 0,11 (ambos com $\mathrm{p}<0,001$ ). Tal descoberta contraria a literatura pesquisada (WANG et al., 2012), mas ainda parece fazer sentido, pois significa dizer que os consumidores que possuam uma forte ligação, senso de pertencimento, com seu grupo de amigos tendem a se comunicar mais do que aqueles que são amigos entre si mas alheios a qualquer grupo. 


\subsection{2.}

\section{Avaliação do impacto normativo e informacional}

No modelo testado nesse estudo foi observada uma relação direta e negativa entre o impacto normativo e a atitude, indicando que, quanto melhor/maior a comunicação com os pares, mais negativa seria a atitude com relação ao produto. Esse resultado é inconsistente e contraria os resultados encontrados por Wang et al. (2012). Entretanto, vale salientar que a magnitude do coeficiente padronizado dessa relação foi bastante baixo $(-0,05)$, o que minimiza um pouco o impacto da comunicação com o grupo de pares mediada pela atitude com relação à intenção de uso. Apesar do impacto normativo não ter sido confirmado diretamente sobre a atitude, o fator informacional foi ratificado, mostrando que os consumidores admitem se inteirar de assuntos com seus pares buscando ativamente por informações ou simplesmente observando seus pares e as mídias sociais auxiliam nessa troca de informações, já que o custo para se ter acesso a tal informação é muito baixo ou inexistente (WANG et al., 2012). Quanto mais informação esses indivíduos recebem, maior o envolvimento com determinado produto ou serviço e consequentemente maiores as chances de desenvolver atitudes positivas com aquele produto ou serviço (KIM, HALEY e KOO, 2009; WANG et al., 2012). Além da verificação da relação direta entre endosso nas mídias sócias e o envolvimento com o produto ou serviço, o modelo também mostra um efeito indireto da conformidade com os pares via envolvimento com o produto, mostrando que, apesar de não ter sido suportada diretamente a influência sobre a atitude em si, a conformidade com os pares afeta a atitude do individuo com relação ao produto ou serviço.

\subsection{3.}

\section{Avaliação do impacto cognitivo}

O modelo apresentado nesse estudo verifica todas as relações e significâncias encontradas no modelo TAM (DAVIS et al., 1989) no que tange as influências de construtos cognitivos sobre a atitude em relação a adoção de um produto ou serviço e também sobre a intenção de uso desse produto ou serviço. Tanto a utilidade percebida como facilidade de uso percebida tiveram efeitos diretos significativos sobre a atitude, mostrando que quanto maior a vantagem 
relativa do produto ou serviço e quanto mais fácil de utilizar tal produto ou serviço for, mais positiva será a atitude do consumidor em relação à intenção de utilizar aquele produto ou serviço.

A facilidade de uso percebida apresentou um efeito positivo, significativo e de alta magnitude, indicando que, quanto maior for a facilidade de uso percebida pelo consumidor, maior a chance de ele perceber utilidade naquela solução. $\mathrm{O}$ mesmo também pode ser concluído da relação entre utilidade percebida e intenção de uso. Tal relação apresentou um efeito positivo significativo e também bastante alto, mostrando que, quanto maior a utilidade que um consumidor perceba em um determinado serviço, maiores as chances daquele consumidor ter intenção de utilizar tal serviço ou produto, resultados que estão em acordo com a literatura visita (DAVIS et al., 1989; KULVIWAT et al., 2007; ROGERS, 2005).

\subsection{4.}

\section{O Impacto do Narcisismo Social}

Um dos objetivos principais do trabalho era o de avaliar o quanto a personalidade de um consumidor influenciaria o seu comportamento em relação a adotar ou não uma nova tecnologia. Duas relações foram avaliadas para o construto narcisismo social: o efeito direto sobre a atitude e o efeito direto sobre a intenção de uso. A literatura sugere que, quanto mais traços narcisistas uma pessoa tiver, maiores são seus comportamentos na direção de: autoridade, exibicionismo, superioridade, título (entitlement), exploração, autossuficiência e vaidade (RASKIN e TERRY, 1988). Por exemplo, existem indícios que apontam para o fato de uma pessoa narcisista ser mais autossuficiente e consequentemente mais suscetível a adotar tecnologias de auto-atendimento. Na questão atitudinal, não foi revelado efeito significativo oriundo de um indivíduo com personalidade narcisista. Entretanto, foi detectada uma relação significativa entre o narcisismo social e a intenção de uso. Apesar do baixo coeficiente padronizado, pela primeira vez é testada em um estudo acadêmico a relação entre a personalidade narcisista e sua inclinação em favor de adotar uma nova tecnologia. 


\subsection{5.}

\section{Influência afetiva sobre a intenção}

Ratificando mais uma vez o apresentado pela literatura (WANG et al., 2012) a atitude foi um forte preditor da intenção de uso da solução. Uma atitude é uma predisposição aprendida para um comportamento consistente favorável com relação a algo (ASSAEL, 1995; SCHIFFMAN e KANUK, 1997). A atitude apresentou o segundo maior efeito sobre a intenção de uso, mostrando que, quanto mais favorável a atitude de um consumidor em relação a um produto, maiores as chances do indivíduo de apresentar um comportamento de fato.

A atitude também afetou direta e significativamente o afeto, indicando que uma pessoa que tenha uma boa predisposição ao comportamento desenvolve uma relação de afeto para com tal comportamento. Entretanto, a relação entre afeto e intenção de uso não foi confirmada. A razão dessa não confirmação pode ter sido causada pelo fato de o afeto ser uma componente da dimensão atitudinal e, por isso, já ter a sua parcela de relação de envolvimento com produto sendo medida diretamente pelo afeto.

A atitude, em linha com a literatura, apresentou efeito direto e negativo sobre a ansiedade, indicando que um individuo que já tenha aprendido a ter uma predisposição favorável a um produto ou serviço deve ficar menos ansioso em utilizar tal produto ou serviço (COMPEAU e HIGGINS, 1999). Por fim, a ansiedade teve um efeito significativo $(<0,05)$ invertido sobre a intenção de uso, o que também era esperado, já que uma pessoa ansiosa e que tenha receio em utilizar um determinado produto ou serviço deve ser menos inclinada a adotar o comportamento de utilizar o produto ou o serviço de fato. 


\section{5 \\ Conclusões}

Este capítulo se inicia com um resumo do estudo apresentado, trazendo alguns resultados e dados importantes que foram obtidos. Em seguida são discutidas as contribuições para a academia e o meio empresarial. Ao final são apresentadas as limitações e sugestões de novas pesquisas.

\section{1. \\ Resumo do Estudo}

Este trabalho investigou a significância de um modelo integrado para adoção de tecnologia que engloba uma perspectiva de socialização do consumo através de mídias sociais com a Teoria Cognitiva Social e a Teoria da Socialização junto com a avaliação de traços de personalidade narcisista dos consumidores. Esse estudo utilizou a tecnologia de auto-atendimento via mídias sociais como a tecnologia a ser adotada pelos consumidores. A forma como essa tecnologia vem sendo adotada, o aumento das pessoas com acesso a internet e que utilizam sites de mídias sociais, tornaram essa tecnologia um interessante tópico para pesquisa.

\section{2.}

\section{Conclusões}

Foram duas as questões de pesquisa propostas no início do trabalho:

1. Os consumidores tem intenção de adotar uma tecnologia que "terceirize" parte das atividades para o próprio consumidor (SAC3C) via sites de mídias sociais?

O modelo proposto captou a percepção da dimensão cognitiva afetando a intenção de adoção de uma tecnologia de auto-atendimento assim como a dimensão afetiva. O modelo também captou a relação de endosso das mídias 
sociais na intenção de adoção de tais tecnologias mostrando que de fato o consumidor tem interesse em utilizar esse tipo de solução e que são sujeitos a influência de seus pares quando optam por adotar tal tecnologia.

2. Como fatores psicológicos dos consumidores afetam a intenção de uso de novas tecnologias que façam uso de mecanismos de $\mathrm{SAC} 3 \mathrm{C}$ via sites de mídias sociais, diretamente e indiretamente via a atitude?

Muito tem se discutido sobre a sociedade cada vez mais narcisista em que vivemos, potencializada pela teoria da autoestima (GUIMARAES et al., 2012) na educação das gerações Y e Z (nascidos entre 1980 e 2010). O estudo mostrou que existe uma relação significativa sobre a intenção de adoção sugerindo que um consumidor com alta autoestima estaria mais propenso a adotar uma tecnologia inovadora e de auto-serviço.

As contribuições deste trabalho para a academia foram duas. Primeiro, os modelos de adoção de tecnologia em grande maioria estudaram tais adoções ou intenções para adoção sob a luz de ambientes empresarias. O presente estudo avaliou a adoção de uma nova tecnologia sob a ótica do consumidor inserido em um ambiente composto por relações virtuais.

Em segundo lugar, este estudo traz uma nova ótica de avaliação não somente das dimensões afetivas e cognitivas como também a inclusão dos traços de personalidade dos consumidores na intensão de uso de soluções de autoatendimento ou auto-serviço.

\section{3.}

\section{Implicações Gerenciais}

O presente estudo mostrou a importância da influência de comunidades virtuais, com especial atenção para aquelas presentes em sites de mídias sociais, sobre a intenção de um consumidor em adotar tecnologias que utilizem SAC3C. Os gerentes devem estar atentos ao poder cada vez maior que os clientes têm sobre as marcas e devem ter a ciência de que o marketing boca-a-boca online pode ser um forte aliado, uma vez que os consumidores depositam mais confiança ao que seus pares estão falando nas mídias sociais do que em propagandas 
tradicionais. O estudo também ratifica a importância de comunicar bem os benefícios da solução ou oferta disponibilizada, já que é grande a parcela de responsabilidade da utilidade percebida pelo consumidor sobre a intenção de adoção.

Por fim, se os gerentes conseguirem ter acesso a informações sobre o perfil psicológico de seus clientes, tal conhecimento poderia ajudar na compreensão da intenção de adoção de uma tecnologia. Entretanto, tais informações são de difícil acesso, apesar de aos poucos surgirem estudos que mostram que é possível se explicar os traços de personalidade de um individuo baseado em seu perfil nas mídias sociais, ampliando ainda mais a importância deste meio de interação com o cliente (KOSINSKI et al.,2013).

\section{4 .}

\section{Limitações}

Apesar de todo o cuidado ter sido tomada na elaboração deste estudo, existem algumas limitações que precisam ser consideradas.

Uma primeira limitação se deve às adaptações feitas na escala 16 NPI de Ames et al. (2006). Com o intuito de realizar um estudo baseado em um modelo de equações estruturais foi necessária a realização de uma adaptação nas escalas alterando o caráter binário da escala para uma escala de diferencial semântico de cinco pontos. Tais adaptações jamais haviam sido propostas e não foram testadas extensivamente antes de sua aplicação neste trabalho. Talvez por essa razão, uma baixa confiabilidade foi verificada para o construto narcisismo social, assim como um baixo valor para a variância média extraída (AVE), ambos inferiores aos limites propostos pela literatura. Essa pode ser uma das razões das baixas correlações com outros construtos durante a fase de avaliação do modelo de mensuração e também dos efeitos do construto narcisismo social sobre atitude não terem sido confirmados. Da mesma forma, isso pode justificar o fato do efeito do narcisismo social sobre a intenção de uso, apesar de significativo, ter sido de pequena magnitude.

Uma segunda limitação se deve ao tipo de tecnologia escolhida para o estudo. Apesar de as soluções de auto-atendimento terem sido constantemente estudadas na academia, a tecnologia de Serviço de Atendimento ao Consumidor 
via mídias sociais ainda não está disponível amplamente para consumidores. Dado este fato, os respondentes que ainda não tiveram como ter contato com a mesma podem ter tido dificuldades em expressar sua atitude e envolvimento com a tecnologia avaliada.

Uma terceira limitação está ligada a amostra. Apesar do número de respondentes ter sido relativamente grande (7555 no total); o perfil da amostra pode não ser suficiente para uma generalização para a população; não existem grandes estudos que mostrem a representatividade de amostras coletadas via internet. Se amostras retiradas de um ambiente virtual não representarem a população em geral, então a generalização dos resultados podem ser comprometidas.

Finalmente, deve-se observar a questão do tamanho do questionário aplicado e o extenso tempo necessário pelos consumidores para respondê-lo, o que poderia cansar o respondente e levar a respostas de menor qualidade (CRONBACH, 2004).

\section{5 . \\ Sugestões para pesquisas futuras}

Estudos futuros devem ser feitos no sentido de melhorar as escalas do construto narcisismo social, o que poderia levar a uma maior significância de tal construto na avaliação da variância da atitude e da intenção de adoção de uma nova tecnologia. Outra opção a ser considerada deve ser a de tentar utilizar um método de multigrupos para avaliar a questão do impacto do narcisismo social.

Com relação à tecnologia adotada para discutir a questão da intenção em utilizar soluções de auto-atendimento via mídias sociais, é necessário explorar melhor o contato do entrevistado com a solução, objetivando capturar melhor o sentimento de utilização desse tipo de solução pelo entrevistado. 


\section{6 \\ Referências Bibliográficas}

AAKER, D. A.; KUMAR, V.; DAY, G. S.; LAWLEY, M. A. John Wiley e Sons Australia, Limited; 2007. Marketing Research: The Second Pacific Rim Edition.

ACKERMAN, R. A.; WITT, E. A.; DONNELLAN, M. B.; TRZESNIEWSKI, K. H.; ROBINS, R. W.; KASHY, D. A. What does the narcissistic personality inventory really measure? Assessment, v. 18, n. 1, p. 67-87, 2011.

AHUJA, M. K.; GALVIN, J. E. Socialization in Virtual Groups. Journal of Management, v. 29, n. 2, p. 161-85, 2003.

ALGESHEIMER, R.; DHOLAKIA, U. M.; HERRMANN, A. The Social Influence of Brand Community: Evidence from European Car Clubs. Journal of Marketing, v. 69, n. 3, p. 19-34, 2005.

AMES, D. R.; ROSE, P.; ANDERSON, C. P. The NPI-16 as a short measure of narcissism. Journal of Research in Personality, v. 40, n. 4, p. 440-450, 2006.

ANANDARAJAN, M.; ZAMAN, M.; DAI, Q.; ARINZE, B. Generation Y Adoption of Instant Messaging: An Examination of the Impact of Social Usefulness and Media Richness on Use Richness. IEEE Transactions on Professional Communication, v. 53, n. 2, p. 132 - 143, 2010.

ASSAEL, H. Consumer Behavior and Marketing Action. Cincinnati: SouthWestern College Publishing, 1995.

BATESON, J. E. G. Self-Service Consumer: An Exploratory Study. Journal of Retailing, v. 61, n. 3, p. 49-76, 1985. 
BAGOZZI, R. P. The Self-Regulation of Attitudes, Intentions, and Behavior. Social Psychology Quarterly, v. 55, n. 2, p. 178-204, 1992.

BANDURA, A. Self-efficacy: Toward a Unifying Theory of Behavioral Change. Psychological review, v. 84, n. 2, p. $191-215,1977$.

BANDURA, A. Reflections on self-efficacy. Advances in Behavior Research and Therapy, v. 1, n. 4, p. $237-269,1978$.

BANDURA, A. Self-efficacy mechanism in human agency. American Psychologist, v. 37, n. 2, p. $122-147,1982$.

BANDURA, A. Social Foundations of Thought and Action, Prentice Hall, Englewood Cliffs, NJ, 1986.

BEARDEN, W. O.; NETEMEYER, R. G.; TEEL, J. E. Measurement of Consumer Susceptibility to Interpersonal Influence. Journal of Consumer Research, v. 15, n. 4, p. 473-81, 1989.

BEEBE, T. J.; MIKA, T.; HARRISON, P. A.; ANDERSON, R. E.; FULKERSON, J. A. Computerized school surveys - Design and development issues. Social Science Computer Review, v. 15, n. 2, p. 159-169, 1997.

BENBASAT, I.; BARKI, H. Quo vadis, TAM? Journal of the Association for Information Systems, v. 8, n. 4, p. $211-218,2007$.

BENTLER, P. M. e BONETT, D. G. Significance Tests and Goodness of Fit in the Analysis of Covariance Structures. Psychological Bulletin, v. 88, n. 3, p. 588606, 1980.

BRANDÃO, E. R. Publicidade on-line, ergonomia e usabilidade: o efeito de seis tipos de banner no processo humano de visualização do formato do anúncio na tela do computador e de lembrança da sua mensagem. Dissertação (Mestrado em Artes e Design) PUC/Rio, Rio de Janeiro. 2006. 
BUFFARDI, L. E.; CAMPBELL, W. K. Narcissism and Social Networking Web Sites. Personality and Social Psychology Bulletin, v. 34, n. 10, p. 1303-1314, 2008.

BYRNE, B. M. Structural Equation Modeling with AMOS: Basic Concepts, Applications and Programming. 2nd ed. Routledge, NY, 2010.

CANEVACCI, M. Quatro mitos para um Narciso "só" - Ide, SP (21), p. 92-101, 1991.

CARPENTER, C. J. Narcissism on Facebook: Self-promotional and anti-social behavior. Personality and Individual Differences, v. 52, n. 4, p. 482-486, 2012.

CHURCHILL, G. A.; MOSCHIS, G. P. Television and Interpersonal Influences on Adolescent Consumer Learning. Journal of Consumer Research, v. 6, n.1, p. 23-35, 1979.

CHURCHILL, G. A. A paradigm for developing Better Measures of Marketing Constructs. Journal of Marketing Research, v. 16, n. 1, p. 64 - 73, 1979.

CODERRE, F., MATHIEU, A., ST-LAURENT, N. Comparison of the quality of qualitative data obtained through telephone, postal and email surveys. International Journal of Market Research, v. 46, n. 3, p. 347-357, 2004.

COMPEAU, D. R.; HIGGINS, C. A. Computer Self-Efficacy: Development of a Measure and Initial Test. MIS Quarterly, v. 19, n. 2, p. 189 - 211, 1995.

COMPEAU, D. R.; HIGGINS, C. A.; HUFF, S. Social Cognitive Theory and Individual Reactions to Computing Technology: A Longitudinal Study. MIS Quarterly, v. 23, n. 2, p. 145 - 158, 1999.

CRESWELL, J. Projeto de pesquisa: métodos qualitativo, quantitativo e misto. 2. ed. Porto Alegre: Bookman, 2010. 
CRONBACH, L J., My current thoughts on coefficient alpha and successors procedures. Educational and Psychological Measurement, v. 64, n. 3, p. 391-418, 2004

CRONIN, J. J.; BRADY, M.; HULT, G. T., Assessing the Effects of Quality, Value, and Customer Satisfaction on Consumer Behavioral Intentions in Service Environments, Journal of Retailing, Vol. 76, No. 2, p. 193-218, 2000.

DAVIS, F. A technology acceptance model for empirically testing new end-user information systems: theory and results. Tese (Ph.D. em gerenciamento) - Sloan School of Management/MIT, Cambridge, MA, EUA, 1986.

DAVIS, F. D. Perceived Usefulness, Perceived Ease of Use, and User Acceptance of Information Technology. MIS Quarterly, v. 13, n. 3, p. 319-339, 1989.

DAVIS, F. D.; BAGOZZI, R. P. e WARSHAW, P. R. User Acceptance of Computer Technology: A Comparison of Two Theoretical Models. Management Science, v. 35, n. 8, p. 982-1002, 1989.

DE BRUYN, A.; LILIEN, G. L. A Multi-stage Model of Word-of-Mouth Influence through Viral Marketing. International Journal of Research in Marketing, v. 25, n. 3, p. 151-63, 2008.

DE GREGORIO, F.; SUNG, Y. Understanding Attitudes Toward and Behaviors in Response to Product Placement: A Consumer Socialization Framework. Journal of Advertising, v. 39, n. 1, p. 83-96, 2010.

DOUGLAS, S. P.; CRAIG, C. S. International Marketing Research. Englewood Cliffs, N.J. Prentice Hall, 1983.

EISENSTEIN, E. ESTEFENON, S. B. Geração digital: riscos das novas tecnologias para crianças e adolescentes. Revista Hospital Universitário Pedro Ernesto, v. 10, n. 2, p. 42-52, 2011. 
FORNELL, C.; LARCKER, D. F. Evaluating Structural Equation Models with Unobservable Variables and Measurement Error. Journal of Marketing Research, v. 18, n. 1, p. $39-50,1981$.

FREUD, S. O mal-estar na civilização. Tradução José Octávio de Aguiar Abreu. Rio de Janeiro: Imago, 1997 (1931).

GARRIGOS-SIMON, F. J.; ALCAMÍ, R. L.; RIBERA, T. B. Social networks and Web 3.0: their impact on the management and marketing of organizations. Management Decision, v. 50, n. 10, p. 1880-1890, 2012.

GERRA, M. Social Networking. The Diagonal, fev. 2014. Disponível em: http://thediagonal.com/tag/social-networking/. Acesso em 16 mar 2014.

GERSHOFF, A.D.; JOHAR, G. V. Do You Know Me? Consumer Calibration of Friends' Knowledge. Journal of Consumer Research, v. 32, n. 4, p. 496-503, 2006.

GUIMARAES, C.; KARAM, L.; AYUB, I. A turma do “Eu me acho”. Época, jul. 2012. Disponível em: http://revistaepoca.globo.com/ideias/noticia/2012/07/turmado-eu-me-acho.html. Acesso em 16 mar 2014.

GUMMESSON, E. Customer centricity: reality or a wild goose chase? European Business Review, v. 20, n. 4, p. 315-330, 2008.

GUMMESSON, E. Quality, service-dominant logic and many-to-many marketing. The TQM Journal, v. 20, n. 2, p. 143-153, 2008.

GUMMESSON, E. Marketing de Relacionamento Total. Porto Alegre: Bookman, 2010.

HART, V. Text Messaging: The Antithesis of Interpersonal Relating. Journal of Psychosocial Nursing e Mental Health Services, v. 48, n. 12, p. 5 - 6, 2010. 
HAFNER, K. Texting May be taking a Toll on Teenagers. The New York Times, mai. 2009. Disponível em:

http://www.nytimes.com/2009/05/26/health/26teen.html. Acesso em 16 de mar 2014.

HAIR, J. F.; BLACK, W. C.; BABIN, B. J.; ANDERSON, R. E. Multivariate

Data Analysis. 7. ed. Upper Saddle River: Prentice-Hall, fevereiro 2009.

HAYES, B. E. Medindo a satisfação do cliente, Rio de Janeiro: Editora Qualitymark, 1995.

HILTON, T.; HUGHES, T.; LITTLE, E.; MARANDI, E. Adopting self-service technology to do more with less. The journal of services marketing, v. 27, n. 1, p. $3-12,2013$.

HORRIGAN, J. B. Consumption of Information Goods and Services in the United States. Pew Internet e American Life Project. Nov. 2003.

HU, P. J.; CHAU, P. Y. K.; SHENG, O. R. L. e TAM. K. Y. Examining the Technology Acceptance Model Using Physician Acceptance of Telemedicine Technology. Journal of Management Information Systems, v. 16, n. 2, p. 91-112, 1999.

JANKOWSKI, N.W; SELM, M. V. Conducting Online Surveys. Quality and Quantity: European journal of methodology, v. 40, n. 3, p. 435 - 456, 2006.

KARMARKAR, U. R.; TORMALA, Z. L. Believe Me, I Have No Idea What I'm Talking About: The Effects of Source Certainty on Consumer Involvement and Persuasion. Journal of Consumer Research, v. 36, n. 6, p. 1033-1049, 2010.

KIM, S.; HALEY, E.; KOO, GY. Comparison of the Paths from Consumer Involvement Types to Ad Responses between Corporate Advertising and Product Advertising. Journal of Advertising, v. 38, n. 3, p. 67-80, 2009. 
KOHLER, C. F.; ROHM, A. J.; DE RUYTER, K.; WETZELS, M. Return on Interactivity: The Impact of Online Agents on Newcomer Adjustment. Journal of Marketing, v. 75, n. 2, p. 93-108, 2011.

KOSINSKI, M.; STILLWELL, D.; GRAEPEL, T. Private traits and attributes are predictable from digital records of human behavior. Proceedings of the National Academy of Sciences, v. 110, n. 15, p. 5802-5805, 2013.

KOTLER, P; KELlER, K, Administração de Marketing. São Paulo: Pearson, 2006.

KULVIWAT, S.; BRUNER II, G. C.; KUMAR, A.; SUZANNE, A. N.; CLARK, T. Toward a Unified Theory of Consumer Acceptance Technology. Psychology and Marketing, v. 24, n. 12, p. 1059-1084, 2007.

LAMANDINI, A. Semantic Web. Ricerche di pedagogia e didattica, v. 6, n.1, p. $1-10,2011$.

LASCH, C. The Culture of Narcissism: American Life in an Age of Diminishing Expectations. Nova Iorque, EUA: Warner Books, 1979.

LEVITT, T. The industrialization of service. Harvard Business Review, v. 54, n. 5, p. 63-74, 1976.

LIN, CH.; YU, SF. Consumer Adoption of the Internet as a Channel: The Influence of Driving and Inhibiting Factors. Journal of American Academy of Business, v. 9, n. 2, p. 112-117, 2006.

LIN, JS. C.; HSIEH, PL. The influence of technology readiness on satisfaction and behavioral intentions toward self-service Technologies. Computer in Human Behavior, v. 23, p. 1597-1615, 2007.

LIU, J. (2010). A conceptual model of consumer sophistication. Innovative Marketing Journal, v. 6, n. 3, 2010. 
LOVELOCK, C. H.; YOUNG, R. A. Look to consumers to Increase Productivity. Harvard Business Review, mai/jun, p. 77-89, 1979.

LUEG, J. E.; PONDER, N.; BEATTY, S. E.; CAPELLA, M. L. Teenagers' Use of Alternative Shopping Channels: A Consumer Socialization Perspective. Journal of Retailing, v. 82, n. 2, p. 137-53, 2006.

LUEG, J. E.; FINNEY, Z. R. Interpersonal Communication in the Consumer Socialization Process: Scale Development and Validation. Journal of Marketing Theory e Practice, n. 15, v. 1, p. 25-39, 2007.

MACIEL, C. Redes sociais são usadas em proporções similares por todas as classes, segundo pesquisa. Agência Brasil, jun. 2013. Disponível em: http://memoria.ebc.com.br/agenciabrasil/noticia/2013-06-20/redes-sociais-saousadas-em-proporcoes-similares-por-todas-classes-segundo-pesquisa. Acesso em 12 mar 2014.

MASON, C.; SIMMONS, J. Are they being served? Linking consumer expectation, evaluation and commitment. Journal of Services Marketing, v. 26, n. 4, p. 227-237, 2012.

MICK, D. G.; FOURNIER, S. Paradoxes of Technology: Consumer Cognizance, Emotions and Coping Strategies. Journal of Consumer Research, v. 25, n.2, p. 123-143, 1998.

MOSCHIS, G. P.; CHURCHILL, G. A. Consumer Socialization: A Theoretical and Empirical Analysis. Journal of Marketing Research, v. 15, n. 4, p. 599-609, 1978.

MUKHOPADHYAY, A.; YEUNG, C. W. M. Building Character: Effects of Lay Theories of Self-Control on the Selection of Products for Children. Journal of Marketing Research, v. 47, n. 2, p. 240-250, 2010. 
MULLEN, M. R. Diagnosing Measurement Equivalence in Cross-National Research. Journal of International Business Studies, v. 26, n. 3, p. 573-596, 1995.

MURATORE, I. Teenagers, Blogs and Socialization: A Case Study of Young French Bloggers. Young Consumers: Insight and Ideas for Responsible Marketers, v. 9, n. 2, p. 131-142, 2008.

NEELY, A. Exploring the financial consequences of the servitization of manufacturing. Operations Management Research, v. 1, n. 2, p. 103-118, 2008.

NIELSEN. 2012. The Social Media Report 2012.

NG, I.; PARRY, G.; SMITH, L.; MAULL, R.; BRISCOE, G, Transitioning from a goods-dominant to a service-dominant logic Visualizing the value proposition of Rolls-Royce, Journal of Service Management, v. 23, n. 3, p. 416-439, 2012.

O'REILlY, T. What Is Web 2.0? O’Reilly.com, set. 2005. Disponível em: http://oreilly.com/pub/a/web2/archive/what-is-web-20.html?page=1. Acesso em: 18 mar 2014.

PAIVA, C. C. O Espírito de Narciso nas Águas do Facebook. As Redes Sociais como Extensões do Ego e da Sociabilidade Contemporânea. Intercom Sociedade Brasileira de Estudos Interdisciplinares da Comunicação XXXV Congresso Brasileiro de Ciências da Comunicação, Fortaleza, CE, set. 2012 .

PEPPERS, D.; ROGERS, M. Managing Customer Relations: a strategic framework. Hoboken, Nova Jersey, EUA: Wiley, 2011.

PRENSKY, M. Digital Natives, Digital Immigrants. On the Horizon, v. 9, n. 5, p. $1-6,2001$. 
RASKIN, R.; TERRY, H. A Principal-Components Analysis of the Narcissistic Personality Inventory and Further Evidence of Its Construct Validity. Journal of Personality and Social Psychology, v. 54, n. 5, p. 890-902, 1988.

ROGERS, E. Diffusion of Innovations, Nova Iorque: Free Press, 2005

RONNINGSTAM, E. Identifying and Understanding the Narcissistic Personality. Cary, NC, Estados Unidos: Oxford University Press, 2005.

SALGANIK, M. J.; DODDS, P. S.; WATTS, D. J. Experimental Study of Inequality and Unpredictability in an Artificial Cultural Market. Science, v. 311, n. 5762 , p. $854-856,2006$.

SANTI, P. L. R. Consumo e desejo na cultura do narcisismo. Comunicação, Mídia e Consumo, v. 2, n. 5, p. 173-204, 2005.

SCHAEFER, D.R.; DILLMAN, D.A. Development of a standard e-mail methodology. Public Opinion Quarterly, v. 62, n. 3, p. 378-397, 1998.

SCHIFFMAN, L. G.; KANUK, L. L. Consumer Behavior. Prentice Hall, 1997.

SEVERIANO, M. F. V.; ALVARO, J. L. Consumo, Narcisismo e identidades contemporâneas. Uma analise psicossocial. Rio de Janeiro: EdUERJ, 2006.

FREUD, S. Obras completas de Sigmund Freud - Sobre o Narcisismo: uma introdução. V. 7, tradução. Dr. C. Magalhães de Freitas et al. Rio de Janeiro: Delta, 1956 (1914).

SHIM, S. Adolescent Consumer Decision-making Styles: The Consumer Socialization Perspective. Psychology and Marketing, v. 13, n. 6, p. 547-569, 1996.

SIVO S. A.; FAN, X.; WITTA, E. L.; WILLSE, J. T. The Search for "Optimal" Cutoff Properties: Fit Index Criteria in Structural Equation Modeling. The Journal of Experimental Education, v. 74, n. 3, p. 267-288, 2006. 
SMITH, A. The Wealth of Nations. Londres, Inglaterra: J. M. Dent, 1910.

SPERBER, A. D. Translation and validation of study instrument for cross-cultural research. Gastroenterology, v. 126, n. 1, p. 124-128, 2004.

SULTAN, F.; ROHM, A. The coming era of "Brand in the Hand" Marketing. MIT Sloan Management Review, v. 47, n. 1, p. 83-90, 2005.

TAGLIAMONTE, S. A.; DENIS, D. Linguistic Ruin? LOL! Instant Messaging and Teen language. American Speech, v. 83, n. 1, p. 3 - 34, 2008.

TAYLOR, D. G.; LEWIN, J. E.; STRUTTON, D. Friends, Fans, and Followers: Do Ads Work on Social Networks? How Gender and Age Shape Receptivity. Journal of Advertising Research, v. 51, n. 1, p. 258-276, 2011.

TOMAS, R. M.; MESCHGRAHW, R. P.; ALCANTARA, R. L. C. AS REDES SOCIAIS E O COMPORTAMENTO DE COMPRA DO CONSUMIDOR: O REINADO DO "BOCA-A-BOCA" ESTÁ DE VOLTA?. REMark - Revista Brasileira de Marketing, São Paulo, v. 11, n. 2, p. 124-151, maio/ago. 2012.

TWENGE, J.; CAMPBELL, W.K. The Narcissism Epidemic: Living in the Age of Entitlement. Free Press, 2009.

UBINHA, P. T; CASSORLA, R. M. S. Narciso: Polimorfismo das versões e das interpretações psicanalíticas do mito. Estudos de Psicologia, v. 20, n. 3, p. 69-81, 2003.

VAGIAS, W. M. Likert-type scale response anchors. Clemson International Institute for Tourism e Research Development, Department of Parks, Recreation and Tourism Management. Clemson University, 2006.

VANDERMERWE, S.; RADA, J. Servitization of business: Adding value by adding services. European Management Journal, v. 6, n. 4, p. 314-324, 1988. 
VARGO, S.L.; LUSCH, R.F. Evolving to a new dominant logic for marketing, Journal of Marketing, v. 68, n. 1, p. 1-17, 2004.

VARGO, S.L.; LUSCH, R.F. The Four Service Marketing Myths: Remnants of a Goods-Based, Manufacturing Model. Journal of Service Research, v. 6, n. 4, p. 324-335, 2004.

VARGO, S.L.; LUSCH, R.F. Service-dominant logic: continuing the evolution. Journal of the Academy of Marketing Science, v. 36, p. 1-10, 2008.

VENKATESH, V.; MORRIS, M. G.; DAVIS, G. B. DAVIS, F. D. User Acceptance of Information Technology: Toward a Unified View. MIS Quarterly, v. 27 , n. 3, p. $425-478,2003$.

VENKATESH, V.; BALA, H. Technology acceptance model 3 and a research agenda on interventions. Decision sciences, v. 39, n. 2, p. $273-315,2008$.

WANG, R. The Evolution of Social CRM. Customer Relationship Management, v.15, n. 9, p. 40-41, 2011.

WANG, X.; YU, C.; WEI, Y., Social Media Peer Communication and Impacts on Purchase Intentions: A Consumer Socialization Framework, Journal of Interactive Marketing, Vol. 26, No. 4, pp. 198-208, Novembro 2012.

WARD, S. Consumer Socialization. Journal of Consumer Research, v. 1, n. 2, p. 1-14, 1974.

WOODCOCK, N.; GREEN, A.; STARKEY, M. Social CRM as a business strategy. Database Marketing e Customer Strategy Management, v. 18, n. 1, p. 5064, 2011.

ZAICHKOWSKY, J. L. Measuring the Involvement Construct. Journal of Consumer Research, v. 12, n. 3, p. 341-352, 1985. 
ZHANG, J.; DAUGHERTY, T. Third-person Effect and Social Networking: Implications for Online Marketing and Word-of-Mouth Communication. American Journal of Business, v. 24, n. 2, p. 53-63, 2009.

ZEITHAML, V. A.; BITNER, M. J. Marketing de serviços: a empresa com foco no cliente. Porto Alegre: Bookmam, 2011. 


\section{Apêndice A - Questionário utilizado na pesquisa}

\section{Instruções:}

Você está prestes a responder a um questionário para fins de pesquisa científica.

É importante que você imagine uma situação onde você precise entrar em contato com a central de atendimento de uma empresa provedora de serviços de telecomunicações (por exemplo para sanar eventuais problemas técnicos ou a solicitação de uma segunda via da fatura para pagamento). Esse contato pode ser feito através dos serviços de 0800 , mas para os fins desse estudo esse contato será feito através da página do Facebook da sua operadora de telecomunicações ou através da conta no Twitter dessa operadora onde você mesmo "navega" na página da mídia social escolhida para selecionar a opção de atendimento que se aproxima da solução procurada.

É isso que você deve ter em mente quando estiver respondendo a perguntas sobre auto-atendimento, ou seja, auto-atendimento ao longo desse questionário é uma forma de atendimento onde você mesmo executa parte da tarefa afim de conseguir chegar na solução final.

Antes de responder ao questionário pedimos que por favor assista ao vídeo:

Tim beta tudo o que você precisa saber (http://www.youtube.com/watch? $v=8 H n c v b 6 Q 7 W 8)$

Por favor, responda a todas as perguntas deste questionário com atenção. Agradecemos desde já sua colaboração.

Caso seja de seu interesse participar do sorteio de um aparelho celular, responda a todas as questões até o final deixando seus dados para contato no caso de ser o sorteado. Boa sorte e obrigado!

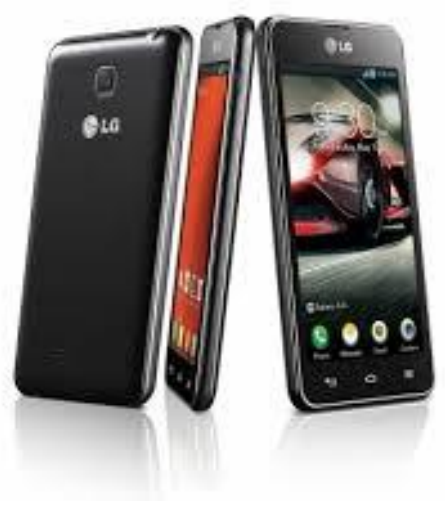




\section{Construto/Indicador}

Questão 1: Com relação a forma como você se relaciona com seus amigos nas mídias sociais:

\section{Força de Ligação com os Pares (escala Likert de cinco pontos de discordo} fortemente a concordo fortemente)

TSP1: Qual a probabilidade de você compartilhar confidências pessoais com seus amigos?

TSP2: Qual a probabilidade de você passar algum tempo livre socializando com seus amigos?

TSP3: Qual a probabilidade de você realizar um grande favor para os seus amigos?

TSP4: Qual a probabilidade dos seus amigos realizarem um grande favor para você?

Questão 2: Com relação a forma como você se identifica com seus amigos nas mídias sociais:

\section{Identificação com o Grupo de Pares (escala Likert de cinco pontos de discordo fortemente a concordo fortemente)}

IPG1: Eu estou muito ligado ao grupo de amigos nas mídias sociais.

IPG2: Meus colegas nas mídias sociais e eu compartilhamos dos mesmos objetivos. IPG3: As amizades que tenho com meus amigos significam muito para mim.

IPG4: Se meus colegas planejassem algo, eu pensaria nisso como algo que "nós" faríamos mais do que "eles" fariam.

IPG5: Eu me vejo como uma parte do grupo de amigos das mídias sociais.

Questão 3: Com relação a forma como você se comunica com seus amigos nas mídias sociais:

Comunicação com os Pares (escala Likert de cinco pontos de discordo fortemente a concordo fortemente)

COM1: Eu frequentemente converso com meus amigos sobre os produtos nas mídias sociais.

COM2: Eu frequentemente converso com meus amigos sobre comprar produtos pela Internet.

COM3: Eu frequentemente peço aos meus amigos conselhos sobre produtos.

COM4: Eu frequentemente obtenho dos meus amigos informações sobre produtos.

COM5: Meus amigos frequentemente me encorajam a comprar produtos.

Questão 4: Lembrando que auto-atendimento é uma forma de solucionar seus problemas junto a operadora de telefonia, onde você entra em contato com a empresa através de aplicativos do tipo Facebook e/ou Twitter ao invés de fazer uma ligação de voz para o SAC da empresa (Serviço de Atendimento ao Consumidor - 0800), informe como você lida com soluções de auto-atendimento:

Afeto (escala Likert de cinco pontos de discordo fortemente a concordo fortemente)

AFE1: Eu gosto de trabalhar com soluções de auto-atendimento.

AFE2: Eu aguardo ansioso pelos momentos da minha vida onde necessito utilizar soluções de auto-atendimento. 


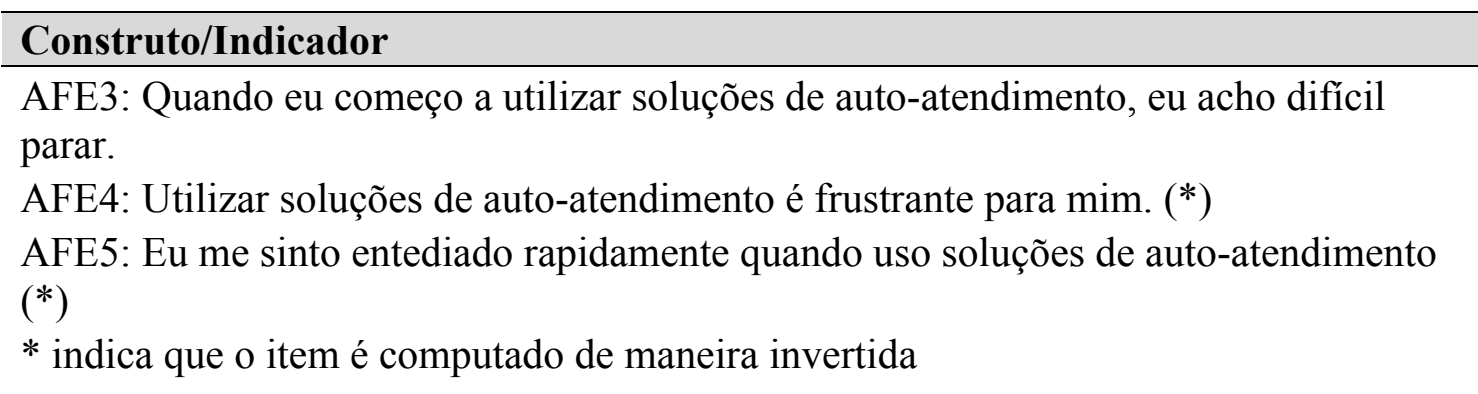

\section{Ansiedade (escala Likert de cinco pontos de discordo fortemente a concordo fortemente)}

ANS1: Eu me sinto apreensivo em utilizar soluções de auto-atendimento.

ANS2: Me assusta pensar que eu poderia perder uma grande quantidade de informação por ter utilizado uma soluções de auto-atendimento de forma incorreta.

ANS3: Eu hesito em usar soluções de auto-atendimento por medo de erros que eu não conseguirei corrigir.

ANS4: Soluções de auto-atendimento são de alguma forma intimidante para mim.

Questão 5: Com relação a sua experiência de uso de soluções de auto-atendimento, responda:

\section{Utilidade Percebida (escala Likert de cinco pontos de discordo fortemente a concordo fortemente)}

UP1: Utilizar soluções de auto-atendimento aumenta minha efetividade em solucionar problemas com a empresa.

UP2: Usar soluções de auto-atendimento me salva tempo em solucionar problemas com a empresa.

UP3: Usar soluções de auto-atendimento aumenta a minha performance em resolver problemas com a empresa.

UP4: Utilizar soluções de auto-atendimento me permitem completar mais tarefas que outros meios.

UP5: No fim, eu vejo que soluções de auto-atendimento me são úteis para resolver problemas com a empresa.

\section{Facilidade de Uso Percebida (escala Likert de cinco pontos de discordo fortemente a concordo fortemente)}

FUP1: Aprender como operar uma solução de auto-atendimento é fácil para mim FUP2: Eu acho fácil fazer as soluções de auto-atendimento obedecerem aos meus comandos.

FUP3: Minha interação com soluções de auto-atendimento é clara e fácil para eu entender.

FUP4: Soluções de auto-atendimento são rígidas e inflexíveis para se interagir. (*)

FUP5: Seria fácil me tornar habilidoso em utilizar soluções de auto-atendimento.

FUP6: Ao fim, eu acho que as soluções de auto-atendimento são fáceis de se usar.

* indica que o item é computado de maneira invertida

Questão 6: Suponha que você tenha acesso a alguma tecnologia de auto-atendimento no futuro qual a probabilidade de você usá-la: 


\section{Intenção de Uso (escala Likert de cinco pontos de discordo fortemente a concordo fortemente)}

IU1: É provável que eu use soluções de auto-atendimento oferecidas pela empresa no futuro.

IU2: É provável que eu recomende soluções de auto-atendimento oferecidas pela empresa para um amigo.

IU3: Se eu tivesse que fazer novamente, eu continuaria utilizando soluções de autoatendimento oferecidas pela empresa.

Questão 7: Precisamos que você julgue através de escalas, como você percebe as soluções de auto-atendimento.

Se você acha que soluções de auto-atendimento é muito mais relacionada a um lado da escala, você deve marcar sua resposta como o exemplo abaixo:

Não importante X:_:_:_:_:_- Importante

$\mathrm{Ou}$

Não importante _:_:_:_:_:X Importante

Procure responder com a maior velocidade possível. Não se preocupe ou reflita longamente. É o seu sentimento imediato sobre soluções de auto-atendimento que queremos. Por outro lado, por favor, não seja descuidado, porque queremos suas verdadeiras impressões.

Lembre-se que auto-atendimento é uma forma de solucionar seus problemas junto a operadora de telefonia, onde você entra em contato com a empresa através de aplicativos do tipo Facebook e/ou Twitter ao invés de fazer uma ligação de voz para o SAC da empresa (Serviço de Atendimento ao Consumidor - 0800).

Em relação ao seu nível de envolvimento e interesse às soluções de auto-atendimento o que melhor descreve suas impressões:

Envolvimento com o Produto (escala de diferencial semântico de cinco pontos)

EP1: Inútil - Útil

EP2: Um benefício - Não é um benefício (*)

EP3: Não desejável - Desejável

EP4: Não necessário - Necessário

* indica que o item é computado de maneira invertida

Questão 8: Sobre as suas atitudes com relação as soluções de auto-atendimento por favor indique:

Atitude com relação ao Produto (escala de diferencial semântico de cinco pontos)

ATT1: Não Gosto - Gosto

ATT2: Ruim - Boa

ATT3: Indesejável - Desejável 


\section{Construto/Indicador}

Questão 9: Leia cada par de comentários abaixo e marque a que mais se aproxima em descrever seus sentimentos e pensamentos sobre você mesmo. Você pode achar que nenhum dos comentários descrevem você bem, mas escolha o que mais se aproxima. Por favor, complete todos os pares.

\section{Narcisismo Social (escala de diferencial semântico de cinco pontos)}

NS1: Eu realmente gosto de ser o centro das atenções - Me deixa desconfortável ser o centro das atenções $(*)$

NS2: Eu não sou melhor ou pior que a maioria das pessoas - Eu acho que eu sou especial

NS3: Todos gostam de ouvir as minhas histórias - Às vezes eu conto boas histórias $(*)$

NS4: Eu normalmente tenho o respeito que eu mereço - Eu luto para ter o respeito que eu mereço (*)

NS5: Eu não me importo em seguir ordens - Eu gosto de ter autoridade sobre as pessoas

NS6: Eu vou ser uma grande pessoa - Eu espero que eu tenha sucesso $\left(^{*}\right.$ )

NS7: As pessoas em alguns casos acreditam no que eu digo para elas - Eu consigo fazer qualquer um acreditar em qualquer coisa que eu diga

NS8: Eu espero muito das outras pessoas - Eu gosto de fazer muito para outras pessoas $(*)$

NS9: Eu gosto de ser o centro das atenções - Eu gosto de estar no meio da multidão $(*)$

NS10: Eu sou muito parecido com outras pessoas - Eu sou uma pessoa extraordinária

NS11: Eu sempre sei o que eu estou fazendo - Às vezes eu não tenho certeza sobre o que eu estou fazendo $(*)$

NS12: Eu não gosto quando eu me percebo manipulando outras pessoas - Eu acho fácil manipular as pessoas

NS13: Ser uma autoridade não significa muito para mim - As pessoas parecem sempre reconhecer a minha autoridade

NS14: Eu sei que eu sou bom porque as pessoas vivem me dizendo isso - Quando as pessoas me elogiam eu fico envergonhado $(*)$

NS15: Eu tento não me destacar tanto - Eu estou pronto para me destacar se eu tiver a chance

NS16: Eu sou mais capaz que as outras pessoas - Eu tenho muito para aprender de outras pessoas $\left(^{*}\right)$

* indica que o item é computado de maneira invertida

\section{Questões Demográficas}

Questão 10: Idade

Questão 11: Sexo

Masculino

Feminino 


\section{Questões Demográficas}

Questão 12: Você possui um smartphone?

Sim

Não

Questão 13: Você faz uso de redes sociais (Facebook, Twitter, Google+ ...) em seu smartphone?

Sim

Não

Questão 14: Você já fez uso de algum tipo de solução de auto-atendimento?

Sim

Não

Questão 15: Informe seu estado civil:

Solteiro(a)

Casado(a)

Separado(a) e/ou Divorciado(a)

Viúvo(a)

Questão 16: Você estima que sua renda familiar média esteja em que faixa de valores:
Abaixo de 1.000 reais
1.000 a 2.000 reais
2.000 a 3.500 reais
3.500 a 6.000 reais
6.000 a 10.000 reais

Acima de 10.000 reais

Questão 17: Informe o seu nível de escolaridade:

Ensino Fundamental (1o. Grau) interrompido

Ensino Fundamental (10. Grau) cursando

Ensino Fundamental (1o. Grau) completo

Ensino Médio (2o. Grau) interrompido

Ensino Médio (2o. Grau) cursando

Ensino Médio (2o. Grau) Profissionalizante cursando

Ensino Médio (2o. Grau) completo

Ensino Médio (2o. Grau) Profissionalizante completo

Formação Superior interrompida

Formação Superior cursando

Formação Superior completa

Pós-graduação no nível Especialização

Pós-graduação no nível Mestrado

Pós-graduação no nível Doutorado

Questão 18: Caso tenha uma linha de telefone móvel. Qual a sua operadora? 


\section{Questões Demográficas}

Claro

OI

Sercomtel

CTBC

Nextel

Questão 19: Qual seu tipo de plano?

Pré-pago

Pós-pago

Outros

Questão 20: Qual o nome do seu plano?

TIM Beta

OI Galera

Outros 


\section{Apêndice B - Tipos de mídias sociais}

- Blogs: Tublr, Wordpress

- Sites de rede social como Facebook, Path, Twitter, Digg, Ning, Google+

- Sites e aplicativos de vídeo como YouTube, Vimeo, Vine

- Aplicativos para música: Soundcloud, Deezer

- Compartilhamento de foto como Flickr, Pinterest, 500px, Instagram

- Aplicativos de menssageria: Whatsapp, Blink, Poke, Snapchat

- Aplicativos de celular interativos como Glio, Glubster

- Aplicativos para postagens anônimas: Whisper e Secret

- Redes baseadas em localização: Foursquare, Swarm, Waze, Yelp, Kekanto

- Sites e aplicativos de emprego: Likenin, Bayt

- Aplicativos de relacionamento: Tinder, Lulu, Star Trek Dating, Date My Pet, Datemyschool, Grouper

- Aplicativos e sites de viagem: Couchsurfing, Travbuddy.com, Tripadvisor, Howaboutwe

- Sites de comparação de produtos

- Fóruns de discussão. 